\title{
Identifying literacy and numeracy skill mismatch in OECD countries using the job analysis method
}

Citation for published version (APA):

Pérez Rodríguez, S., van der Velden, R., Huijts, T., \& Jacobs, B. (2022). Identifying literacy and numeracy skill mismatch in OECD countries using the job analysis method. ROA. ROA Research Memoranda No. $011 \mathrm{https}: / /$ doi.org/10.26481/umaror.2021011

Document status and date:

Published: 04/01/2022

DOI:

10.26481/umaror.2021011

Document Version:

Publisher's PDF, also known as Version of record

\section{Please check the document version of this publication:}

- A submitted manuscript is the version of the article upon submission and before peer-review. There can be important differences between the submitted version and the official published version of record.

People interested in the research are advised to contact the author for the final version of the publication, or visit the DOI to the publisher's website.

- The final author version and the galley proof are versions of the publication after peer review.

- The final published version features the final layout of the paper including the volume, issue and page numbers.

Link to publication

\footnotetext{
General rights rights.

- You may freely distribute the URL identifying the publication in the public portal. please follow below link for the End User Agreement:

www.umlib.nl/taverne-license

Take down policy

If you believe that this document breaches copyright please contact us at:

repository@maastrichtuniversity.nl

providing details and we will investigate your claim.
}

Copyright and moral rights for the publications made accessible in the public portal are retained by the authors and/or other copyright owners and it is a condition of accessing publications that users recognise and abide by the legal requirements associated with these

- Users may download and print one copy of any publication from the public portal for the purpose of private study or research.

- You may not further distribute the material or use it for any profit-making activity or commercial gain

If the publication is distributed under the terms of Article $25 \mathrm{fa}$ of the Dutch Copyright Act, indicated by the "Taverne" license above, 


\section{Maastricht University $\$$ ROA}

\section{Identifying literacy and numeracy skill mismatch in OECD countries using the job analysis method}

Sandra Pérez Rodríguez

Rolf van der Velden

Tim Huijts

Babs Jacobs

\section{ROA Research Memorandum}

ROA-RM-2021/11

Researchcentrum voor Onderwijs en Arbeidsmarkt | ROA Research Centre for Education and the Labour Market / ROA 


\title{
Identifying literacy and numeracy skill mismatch in OECD countries using the job analysis method
}

\author{
Sandra Pérez Rodríguez \\ Rolf van der Velden \\ Tim Huijts \\ Babs Jacobs
}

ROA-RM-2021/11

December 2021

Research Centre for Education and the Labour Market Maastricht University

P.O. Box 616, 6200 MD Maastricht, The Netherlands

$\mathrm{T}+31433883647$

secretary-roa-sbe@maastrichtuniversity.nl

www.roa.nl

ISSN: $2666-8823$ 


\section{Abstract \\ Identifying literacy and numeracy skill mismatch in OECD countries using the job analysis method*}

Skill mismatches have strong negative effects on productivity, job satisfaction, and other outcomes. To reduce skill mismatches, governments need to rely on accurate data on the prevalence of these mismatches. The Programme of the International Assessment of Adult Competences (PIAAC) is currently the most important data source providing excellent and unparalleled information for many countries on two key informationprocessing skills (i.e., literacy and numeracy skills). However, although these data contain rich information about possessed skills, countries lack directly comparable information on the required skills in those domains. Hence, it has been difficult to use the PIAAC data to identify skill mismatches, other than through proxies of required skills (e.g., the average skill level in occupations) or workers' self-assessments of skill mismatch.

In this paper, we use the Job Analysis Method (JAM) to determine the required skill levels of literacy and numeracy for all 4-digit ISCO08 unit groups of occupations in the same metric and scale as was used in PIAAC. JAM involves the use of occupational experts to rate the skill requirements in the different occupations. JAM has never been used before to identify required skill levels for literacy and numeracy as measured in PIAAC, and the paper thus presents the first results on the prevalence of skill shortages and skill surpluses in these key information-processing skills across different OECD countries and across different occupations and sectors that is based on a more direct estimate of the required skills. We provide estimates for the proportions of well-matched, overskilled and underskilled workers per country, and compare these with estimates based on alternative methods for estimating skill mismatch. We also compare JAM with these other methods in explaining wage differentials, as well as job satisfaction. We conclude that there are large differences in the estimates of the prevalence of skill mismatches depending on the method used. We show several advantages using JAM and discuss some of the limitations as well.

JEL classification: 126, J24

Keywords: skill shortages, underskilling, skill surpluses, overskilling, skill mismatch, wages, job analysis method, realized matches approach

\footnotetext{
This paper is part of a larger project conducted by the authors together with a group of experts: Margaret Birch, Peter Elias, Christy Gregory, David Hunter, Phil Lewis, Jean-François Rouet, Folker Schrödel, and David Tout. We are very grateful to them for their continued support for and dedication to the project. We also thank Marco Paccagnella, Glenda Quintini, and William Thorn from the OECD for their comments and suggestions during the project. The research was supported by a grant from NWO-NRO on behalf of the Dutch Ministries of Education, Culture and Science, Economic Affairs, and Social Affairs and Employment (grant 405-17-900/3504). We particularly thank Ted Reininga from the Ministry of Education, Culture and Science for his support for the project, and for his comments and suggestions.
} 
Sandra Pérez Rodríguez

Maastricht University

ROA

P.O. Box 616

NL-6200 MD Maastricht

The Netherlands

s.perezrodriguez@maastrichtuniversity.nl

Tim Huijts

Maastricht University

ROA

P.O. Box 616

NL-6200 MD Maastricht

The Netherlands

t.huijts@maastrichtuniversity.nl
Rolf van der Velden

Maastricht University

ROA

P.O. Box 616

NL-6200 MD Maastricht

The Netherlands

r.vandervelden@maastrichtuniversity.nl

Babs Jacobs

Maastricht University

ROA

P.O. Box 616

NL-6200 MD Maastricht

The Netherlands

bpja.jacobs@maastrichtuniversity.nl 


\section{Introduction}

Skill mismatch refers to a situation in which the level of skills possessed by the worker does not correspond to the level of skills required by the job (European Centre for the Development of Vocational Training 2014; McGuinness, Pouliakas, and Redmond 2018). Skill surplus or overskilling represents a situation in which the worker's potential is not fully exploited, while skill shortage or underskilling represents a situation in which the job's requirements are not optimally fulfilled. Matching theories have pointed out that workers reach an optimal productivity in their job if the possessed skills are in line with the required skills (Sattinger 1993, 2012; Hartog 2000). This is confirmed in many empirical research findings across western countries. The wage returns for overskilled workers are less than for similar workers who are well-matched, while underskilled workers usually face a wage penalty (Groot and Maassen van den Brink 2000; McGuinness 2006; Nordin, Persson, and Rooth 2010; Quintini 2011). Skill mismatches do not only affect wages, but also job satisfaction and other outcomes (Allen and van der Velden 2001; McGuinness and Wooden 2009). Note that in the case of job satisfaction, minor underskilling may still have a positive effect (van der Velden and Verhaest 2017).

Both skill surpluses and skill shortages may hamper economic growth (Quintini 2011, 23). Therefore, skills policies figure prominently on the policy agenda (Global Agenda Council on Employment 2014; Cedefop 2015; OECD 2016; McGowan and Andrews 2017). There is evidence that the degree of skill mismatch in OECD countries persists over time (OECD 2016), but also varies considerably across countries (Wolbers 2003; Muñoz de Bustillo Llorente et al. 2018). To design an optimal skills policy, governments need to rely on accurate data on the prevalence of skill mismatches. Although attempts have been made to identify skill shortages and skill surpluses in a more systematic way (CEDEFOP 2018; The Skills Panorama project by CEDEFOP, 2020), good indicators for important skill domains like literacy and numeracy are still lacking. Literacy and numeracy are key information-processing skills that are essential for functioning well in the job. This is not only because these skills are required in the job, but also because these skills are prerequisites for acquiring both job-specific technical skills and other general skills that are crucial. This also explains why skill mismatches in these domains explain educational mismatches to a large degree (Levels, van der Velden, and Allen 2014). Additionally, these skills are among the strongest predictors of economic and non-economic outcomes (OECD 2016).

With the arrival of the large-scale Programme of the International Assessment of Adult Competences (PIAAC; OECD 2013a, 2013c, 2013b), countries have excellent and unparalleled information on the possessed literacy and numeracy skills of their workers, but they lack equivalent occupational information on the required skills in those domains. While there is some information on required literacy and numeracy skill levels available from other sources (e.g., the requirements regarding Reading Comprehension and Mathematics in the US Occupational Information Network O*NET 2019), this information does not match with the definition of literacy and numeracy in PIAAC, nor does it provide those skill levels in the same metric and scale as the PIAAC skill proficiency scales. Hence it is impossible to use the PIAAC data to directly identify potential shortages or surpluses in these areas. Although proxies have been used to measure the required skill levels in these domains (e.g., Allen, Levels and van der Velden, 2013; Perry, Wiederhold, and Ackermann-Piek 2014; Pellizzari and Fichen 2013, 2017), these proxies have important inherent weaknesses (van der Velden and Bijlsma 2019).

In this paper we will use the so-called Job Analysis Method (JAM) to assess the required skill levels of two key information-processing skills (i.e., literacy and numeracy) for all 4-digit International Standard Classification of Occupations 2008 (ISCO08) unit groups of occupations 
(International Labour Organization 2012) in the same metric and scale as was used in PIAAC. JAM has never been used before to identify required skill levels for literacy and numeracy as measured in PIAAC, and the paper thus presents the first results on the prevalence of skill shortages and skill surpluses in these key information-processing skills across different OECD countries and across different occupations and sectors that is based on a more direct estimate of the required skills. This is a major contribution to the skill mismatch literature as literacy and numeracy are considered to be the most important skills that affect economic and non-economic outcomes (OECD 2016; Levels et al. 2014). Moreover, we also examine to what extent the skill mismatch estimates derived with JAM can explain wage differentials and job satisfaction, and how the explanatory power of these estimates compares to estimates based on other methods to determine skill mismatch.

The paper proceeds as follows. In Section 2 we briefly review existing methods to measure skill mismatches in the domains of literacy and numeracy. Section 3 describes how we applied JAM. Section 4 outlines the data and analysis plan. In Section 5 we provide estimates for the proportions of well-matched, overskilled and underskilled workers per country, per occupation and per sector using JAM and compare these with alternative estimates. In this section, we also compare JAM with other methods in explaining wage differentials, as well as job satisfaction. Section 6 concludes and discusses limitations, implications for policy makers and future directions for research.

\section{Measuring skill mismatch}

In the literature, four different methods can be distinguished to measure skill mismatch: JAM (asking job experts to assess the required level of skills in different occupations), worker selfassessment (WSA: asking workers to assess the level required for their job), the realized matches approach (RMA: taking the average or median possessed skill level of workers in an occupation as a proxy for the required level in that occupation), and the job requirement approach (JRA: taking the frequency of use of certain skills by workers in a job as a proxy for the required level of such skills in that job). It is important to note that each of these methods serve different purposes and all have their pros and cons (see also Table 1 for a short summary).

JAM involves the assessment of skill requirements in jobs by occupational experts (Hartog 2000; Verhaest and Omey 2006; McGuinness, Pouliakas, and Redmond 2018). The primary purpose of JAM has been referred to as having an 'objective' indication of the prevalence of skill surpluses and skill shortages (Hartog 2000). However, the core methodology is that occupational experts assess what would be the optimal or critical skill requirements to function well in a job. Therefore, JAM is also sometimes referred to as the 'normative' approach. JAM is only considered a valid approach if the information used by the experts is accurate and up to date (van der Velden and van Smoorenburg 1997; Dahlstedt 2011). Moreover, a problem with using JAM is that experts cannot assess each individual job. Instead, JAM relies on assessing required levels for jobs that are grouped into occupational clusters in an occupational classification, thus disregarding within-occupation heterogeneity. Another obstacle using JAM is that it is a rather time-consuming and thus expensive method to assess skill mismatches.

WSA is the subjective counterpart of JAM. The primary purpose of WSA is to assess to what extent workers themselves believe that they are overskilled or underskilled. A typical question might be: "Which of the following alternatives would best describe your skills in your own work?" with answers 1) "I need further training to cope well with my duties," 2) "My present skills 
correspond well with my duties," and 3) "I have the skills to cope with more demanding duties." (European Working Conditions Survey: Eurofound 2012). WSA has been criticized, mainly because workers are likely to overestimate their job's skill requirements (Allen and van der Velden 2005; Perry et al. 2014), thus causing a bias in the estimates. Still, it might give very useful information, specifically when compared with JAM. Apart from identifying skill mismatches, it is important to know whether workers are aware of these mismatches. Skill policies to improve workers' skills are unlikely to be successful if workers themselves believe there is no mismatch. Although it is likely that WSA is strongly correlated to other subjective outcomes such as job satisfaction, it is difficult to interpret this due to reverse causality (i.e., job satisfaction might affect the answers to the WSA questions).

RMA relies on using the average or median skill level in an occupation and identifies the overand underskilled workers in that occupation by using a cut-off point of usually one standard deviation. Note that, by definition, RMA defines the average worker in an occupation as being well-matched, without considering the real requirements of the job (Desjardins and Rubenson 2011). Therefore, the primary purpose is not to assess the actual extent of skill surpluses or shortages in a country but to provide a proxy that can be used when assessing the effects of skills mismatches on outcomes. For this purpose, RMA is a relatively valid method, and easy to apply. Like JAM, RMA relies on estimates per occupation and ignores within-occupation heterogeneity.

The fourth approach, the JRA, was initially developed by Green, Felstead, and Gallie (2013) for the British Skills Survey and was also used to measure skill mismatches in PIAAC (Allen et al. 2013). JRA focuses on the time intensity or frequency of using certain skills. A typical question would be: "In your job, how often do you usually read letters, memos, or e-mails?" with answers ranging from 'never' to 'every day' (PIAAC; OECD 2013c). A set of items relating to a certain skill domain is then used to construct a scale on skill use. The interpretation of this scale is that it reflects the skill requirements on the job (hence the term job requirement approach). The assumption is that a high level of skill use reflects a higher level of required skills. JRA is criticized as the use of skills might simply not be a good proxy of skill requirements and is also measured in a different metric than skill proficiency (Perry et al. 2014). Still, in a literal sense, it might reflect tensions at an individual level on the extent to which workers need to use their skills at a higher level than their proficiency level would allow. This tension might certainly be related to outcomes such as job satisfaction. 
Table 1

Overview of different skill mismatch methods

\begin{tabular}{|l|l|l|l|}
\hline Method & Primary goal & Pros & Cons \\
\hline JAM & $\begin{array}{l}\text { Objective or normative } \\
\text { assessment of skill } \\
\text { mismatches }\end{array}$ & $\begin{array}{l}\text { Experts' views on critical } \\
\text { skill requirements } \\
\text { Required skills are } \\
\text { assessed directly, rather } \\
\text { than approached } \\
\text { through proxies }\end{array}$ & $\begin{array}{l}\text { Ignores within-occupation } \\
\text { heterogeneity } \\
\text { Expensive } \\
\text { Risk of inaccurate and out of } \\
\text { date information as it is based } \\
\text { on existing task descriptions }\end{array}$ \\
\hline WSA & $\begin{array}{l}\text { Subjective assessment of } \\
\text { skill mismatches }\end{array}$ & $\begin{array}{l}\text { Easy to apply } \\
\text { Individual job level }\end{array}$ & $\begin{array}{l}\text { Social bias } \\
\text { Reverse causality with relevant } \\
\text { outcomes }\end{array}$ \\
\hline RMA & $\begin{array}{l}\text { Assessment of average or } \\
\text { median skill level } \\
\text { Proxy of skill mismatches to } \\
\text { be used in analyses of } \\
\text { outcomes }\end{array}$ & Easy to apply & $\begin{array}{l}\text { Average worker by definition } \\
\text { well-matched } \\
\text { lgnores within-occupation } \\
\text { heterogeneity }\end{array}$ \\
\hline JRA & $\begin{array}{l}\text { Assessment of relative skill } \\
\text { use } \\
\text { Proxy of skill mismatches to } \\
\text { be used in analyses of } \\
\text { outcomes }\end{array}$ & $\begin{array}{l}\text { Easy to apply } \\
\text { Individual job level }\end{array}$ & $\begin{array}{l}\text { Skill use is not the same as skill } \\
\text { requirement } \\
\text { Scales not comparable which } \\
\text { makes the definition of well- } \\
\text { matched difficult }\end{array}$ \\
\hline
\end{tabular}

In this paper, we will use JAM to identify required literacy and numeracy skill levels for workers in OECD countries, using PIAAC data. JAM enables us to provide a direct estimate of the prevalence of skill mismatches across countries that does not rely on proxies of required skills or on workers' self-assessments of skill mismatch. We compare these estimates of the prevalence of skill surpluses and skill shortages with proxies based on variations of RMA. This comparison will allow countries to assess to what extent they would arrive at different conclusions on the prevalence of skill mismatches if they base their skill policies on JAM or on these proxies, and to what extent the estimates from the various methods are in line with the existing literature on skill mismatch. We do not compare our results with WSA, as in PIAAC the WSA questions refer to general skill mismatch, and not to mismatch in the domains of literacy and numeracy. Apart from that, the WSA questions were not well posed, leading to a serious underestimation of the proportion of well-matched workers. ${ }^{1}$ We will also not compare our results with JRA as this is a different concept comparing workers' skill use to their own skill proficiencies.

Apart from having good estimates of the size of skill mismatches, policy makers and researchers are also interested in the effects of skill mismatches on a range of outcomes. This is a different issue, and we can derive different expectations about which method performs best at predicting outcomes such as wages or job satisfaction. The extent to which JAM or RMA is better at predicting wage effects of skill mismatches is dependent on the wage setting regime. If wages are solely based on inherent job requirements, one would expect JAM to predict wages better than RMA. However, if employers base their wages on average characteristics of their workers, then RMA is more likely to predict the wages correctly.

1. Based on the sample we use in this paper, the proportion of well-matched is estimated to be only $9 \%$ of the workers if we rely on the WSA questions. 
In the case of job satisfaction, the mechanism is slightly different. Job satisfaction is mainly driven by whether workers' initial expectations about the job conditions are being met (Warr 2007, 2013). These expectations can be based on the job's inherent characteristics (as being assessed in JAM) or based on what people observe for workers with a similar background (which is typically measured in RMA). If the latter is the dominant mechanism, we would expect that RMA predicts job satisfaction better than JAM. The extent to which this is the case is an empirical question which will be addressed in this paper.

\section{Applying JAM to determine required literacy and numeracy}

The contribution of this paper to the existing literature is that we use JAM to determine the required skill levels for literacy and numeracy ${ }^{2}$ for almost every ISCO 4-digit unit group: a total of 433 occupational unit groups. For the assessment, six international occupational experts who were all very experienced in rating skill requirements in national and international settings and two domain experts in the areas of measuring literacy and numeracy were brought together. The domain experts were included to ensure that the occupational experts were trained to be familiar with the concepts and frameworks used to measure literacy and numeracy in PIAAC (for more details on the project, see Pérez Rodríguez et al. 2020).

The concept of numeracy in PIAAC is defined as "the ability to access, use, interpret and communicate mathematical information and ideas in order to engage in and manage the mathematical demands of a range of situations in adult life" (OECD 2013b, 20). Literacy is defined as "the ability to understand, evaluate, use and engage with written texts to participate in society, to achieve one's goals, and to develop one's knowledge and potential. It encompasses a range of skills from the decoding of written words and sentences to the comprehension, interpretation, and evaluation of complex texts" (OECD 2013b, 20). It should be noted here that writing skills are not covered in the literacy framework of PIAAC. The reason for this is partly practical: it is difficult to assess writing skills through test-based assessments, especially if the aim is to achieve comparable skill proficiency scores across countries.

For both literacy and numeracy, the PIAAC framework distinguishes five different levels (for an overview, see Appendix A; for more information, see OECD 2013b). To illustrate, the description for a literacy task at level 1 starts with: "Most of the tasks at this level require the respondent to read relatively short digital or print continuous, non-continuous, or mixed texts to locate a single piece of information that is identical to or synonymous with the information given in the question or directive ....." (OECD 2013b, 69-70). At level 5, the literacy requirements start with: "At this level, tasks may require the respondent to search for and integrate information across multiple, dense texts; construct syntheses of similar and contrasting ideas or points of view; or evaluate evidence-based arguments...." (ibid). These examples show that the PIAAC assessment of literacy and numeracy goes beyond basic reading and numeracy and ranges from very basic to very complex levels. Just to give an indication: some $17 \%$ of the population of working adults in OECD countries have a proficiency level for literacy of level 1 or below, while only $1 \%$ reaches proficiency level 5 . For numeracy, these proportions are respectively $19 \%$ and $1 \%$.

For the assessment, we went through the following phases:

2. PIAAC also assessed a third domain, Problem Solving in Technology-Rich Environments. However, as not all respondents took this test and the measurement will change between the first and the second cycle of PIAAC, we decided to focus only on literacy and numeracy. 
- Phase 0: Pilot study to develop the proof of concept for a limited number of exemplary occupations. In the pilot study we developed the background material for the experts, consisting of 2-page notes for each 4-digit occupational unit group with a list of tasks and examples of job titles, as well as the required education and experience to do the job (for relevance, Surrette, Aamodt, and Johnson 1990; Dierdorff and Wilson 2003; Jenkins and Curtin 2006).

- Phase 1: Plenary session in which the concepts and frameworks of literacy and numeracy were explained by the domain experts (these were the chairs of the PIAAC literacy and numeracy expert groups).

- Phase 2: Plenary sessions in which for each of the ISCO 2-digit Sub-Major Groups, one socalled anchor occupation was discussed jointly. These anchor occupations (40 in total) were chosen to be the most representative 4-digit occupational unit group in that Sub-Major Group. The domain experts were present during these sessions to help the occupational experts in applying the PIAAC framework to the literacy and numeracy requirements in the anchor occupation (for relevance of joint training, see Voskuijl and van Sliedregt 2002; Lievens and Sanchez 2007). The six occupational experts needed to reach unanimous decisions on the required literacy and numeracy levels for each of these anchor occupations.

- Phase 3: The anchor occupations were used as a starting point to rate all occupational unit groups in relation to the corresponding anchor in that Sub-Major Group. This was done in two subgroups. In each subgroup three occupational experts rated a set of occupations, all belonging to the same 2-digit Sub-Major Groups. Subgroups were formed to be as diverse as possible (Mullins and Kimbrough 1988) and changed in composition after rating half of the unit groups. Experts were asked to rate a set of occupations individually in advance. After receiving the initial ratings, occupations that were (almost) unanimously rated were not further discussed. This applied to some two thirds of the occupations. The remaining one third of the occupations was discussed in a subgroup session. In most cases, one of the three experts disagreed with only one level difference and only in less than $10 \%$ of the cases there was more disagreement. If the three experts could not reach full agreement, the occupation in question was referred to Phase 4.

- Phase 4: Plenary session in which occupations were discussed for which a subgroup could not find full agreement. This applied only to three occupational unit groups.

- Phase 5: Plenary session with all experts, including the domain experts, in which an overview of the ratings for all occupations was discussed. Instead of discussing the occupations per Sub-Major Group, all occupations were now rank ordered by required level. By discussing them in this way we wanted to ensure consistency across the different SubMajor Groups. This final review did not lead to any changes in the original ratings.

It is important to keep the following characteristics of the rating process in mind:

- The assessment of the required level is based on the international ISC008 task description (International Labour Organization 2012). This means that the required level for a certain unit group of occupations is the same in all countries regardless of the actual skill proficiency level in those countries. This is possible as ISCO is task-based: if an occupation in a country represents other tasks and thus other skill requirements, this should be reflected in coding this to a different occupation in ISCO.

- Experts were asked to rate the critical required level, that is the minimum level of skills required to do the job, rather than the optimal required level.

- Experts were asked to look at the current required levels. This means that in some cases they used other information than the ILO task descriptions if they thought that these were outdated. This ensures that the assessment is up to date. 
- Experts were asked to assess the level required for standard jobs within the unit group, rather than that required for junior or senior positions.

- In some cases, the required level of literacy or numeracy was in-between two adjacent levels. In those cases, the experts assigned an in-between level (e.g., level 2.5). This happened in $26 \%$ of the cases for numeracy and $27 \%$ for literacy.

- In some cases, the 4-digit occupational unit groups were rather heterogeneous, consisting of occupations that vary in required level. In those cases, experts gave combined ratings (e.g., level $2+3$ ). This happened in $13 \%$ of the cases for numeracy and $8 \%$ for literacy.

An overview of the resulting scores per ISCO 4-digit occupation is given in Supplementary Materials, Appendix C.

\section{Data and analysis}

\subsection{Data and sample selection}

To date, PIAAC covers a total of 38 different countries. PIAAC collects data from national representative samples of individuals ranging from 16 to 65 years old. It includes direct measures of adults' proficiency in several key skill domains (with scores ranging from 0 to 500 ), as well as a series of questions regarding the use of these skills at work and at home. Furthermore, PIAAC includes a background questionnaire comprising demographic, educational, and labor status information (OECD 2013c).

For the current analysis, we used data from 31 OECD countries that participated in PIAAC. We focus only on OECD countries given that the ratings were decided with the OECD target population in mind. Therefore, we exclude Cyprus, Ecuador, Kazakhstan, Peru, Russia and Indonesia as they are not OECD members. We also excluded Australia due to issues around data protection legislation. From the Canadian sample, we took a random sample of about 20 percent to avoid overrepresentation of that country in the dataset. We excluded individuals who are unemployed or out of the labour force, people working in occupations related to the armed forces (in compulsory military or community service as well as military workers), unpaid family workers, and respondents who stated that their main status is student or intern, as for these workers the relation between wages and skill requirements is less well defined. We excluded respondents with a missing value on one of the variables in the analysis (this led to only $3.1 \%$ loss as item non-response is very low in PIAAC). We also excluded respondents for which we only have occupation codes available at the first digit (ISCO Major Group). The analytical sample consists of 103,115 employees working in 31 industrial countries. In the wage analyses we excluded the self-employed and trimmed the wages per country leaving out the $1^{\text {st }}$ and $99^{\text {th }}$ percentile, thus having an analytical sample of 84,078 respondents.

\subsection{Comparison between JAM and other skill mismatch measures}

In the analysis, we compare JAM with four other empirical skill mismatch measures: three different specifications of the RMA and the Pellizari-Fichen Model (PFM). For the RMA, we follow Perry et al. (2014). They assess the average skill level per country for each two-digit ISCO Sub-Major Group and use a cut-off point of one standard deviation to identify the overand underskilled. Note that this specification differs in two respects from JAM: first, it is countryspecific and, second, it is based on 2-digit Sub-Major Groups instead of 4-digit unit groups. Therefore, we will also assess a similar version of RMA using 4-digit codes across all countries as well as a version using 2-digit codes across all countries. 
PFM is a rather innovative model developed by Pellizzari and Fichen (2013), combining elements of the WSA and RMA. First, they selected all workers who identified themselves as being well-matched, based on two questions in the PIAAC survey: "Do you feel that you have the skills to cope with more demanding duties than those you are required to perform in your current job?" and "Do you feel that you need further training in order to cope well with your present duties?" The authors then assessed the range of skill proficiency levels of all the workers who identified themselves as well-matched per country for each 1-digit ISCO Major Group of occupations, excluding Major Group 6 (1.6\% of the observations) and Major Group 0, the latter having been already left out of our analytical sample as it refers to the armed forces. In addition, they treat Major Groups 1 and 2 as a unique category (Pellizzari and Fichen 2013). ${ }^{3}$ This skill proficiency range was then trimmed (omitting the lower and upper 5\%) and regarded as the "normal" skill range in that Sub-Major Group. Any worker - regardless of what he or she answered to the two subjective questions - was considered well-matched if their skill proficiency levels fell in the country-occupation specific skill ranges. Anyone with a skill proficiency level above the $95 \%$ score was defined as overskilled and anyone below the $5 \%$ range was defined as underskilled.

Note that both country-specific estimates (Perry et al. 2014 and Pellizari and Fichen 2013) are based on 2-digit Sub-Major Groups respectively 1-digit Major Groups. Given the small number of observations per country, it is not possible to derive these estimates at the more detailed 4digit unit group level. We decided not to compare our JAM measure to the recently developed effective skill measure (van der Velden and Bijlsma 2019). The rationale of the effective skill measure is that skills only affect wages through the use of relevant skills. In their specification, van der Velden and Bijlsma (2019) also use an RMA approach but based on the product of skills proficiency and skill use. Comparing this to JAM would not be fair, as in developing the JAM measure, we only gathered information on the required skill proficiency according to occupational experts and not on the required skill use according to occupational experts.

\subsection{Analytic strategy and models}

In all analyses, we will follow the conventional so-called overeducation-required educationundereducation model (ORU) developed by Duncan and Hoffman (1981). In this model, a worker's skill proficiency level (WSP) is broken down into its three components:

- Required Skill Proficiency (RSP)

- OverSkilling Proficiency (OSP), defined as WSP - RSP if WSP > RSP and zero otherwise

- UnderSkilling Proficiency (USP) defined as RSP - WSP if WSP < RSP and zero otherwise. In formula:

WSP $=$ RSP + OSP - USP

Although JAM intends to provide us with a good measure of RSP, we still need to define in which cases there is a match (when is WSP equal, lower or higher than RSP?). In RMA this is defined as having a skill difference of one standard deviation. For JAM we will use the same range of one standard deviation.

3. Pellizzari and Fichen (2017) used two-digit ISCO Major Groups; however, using this approach led to a large drop of observations, as there were many cases in which there were not enough (if any) workers who self-defined as well-matched in each Sub-Major Group per country. We have decided to use the 1-digit instead for the analysis to allow for a fair comparison with JAM and RMA. 
For RSP we will use the midpoint of the required level as indicated by the experts. In consultation with the experts, and in line with the common practice in PIAAC, we decided not to make a distinction between levels 4 and 5 . The number of respondents reaching a level 5 proficiency is very low (only 1\% for both literacy and numeracy (OECD 2019)) and it was felt that it is difficult to define mismatches at this very high end of the scale. An overview of these midpoints is given in Table 2, column 2. Given the fact that each level in PIAAC comprises a range of 50 points, the range of well-matched is set at 100 points (which is roughly equivalent to two standard deviations (OECD 2013b: p. 61). This means that someone with a proficiency level of at least 50 points (or 1 standard deviation) higher than the RSP is defined as overskilled and someone with a proficiency level of at least 50 points lower is defined as underskilled. For the so-called combined ratings, we used the full range of both levels. The resulting ranges are shown in column 3 of Table 2.

\section{Table 2}

Required proficiency levels and range in proficiency levels of well-matched workers using JAM

\begin{tabular}{|l|l|l|}
\hline Level & RSP & Range well-matched \\
\hline $\mathbf{0}$ & 150 & $1-200$ \\
\hline $\mathbf{0 . 5}$ & 175 & $126-225$ \\
\hline $\mathbf{0 + 1}$ & 175 & $1-250$ \\
\hline $\mathbf{1}$ & 200 & $151-250$ \\
\hline $\mathbf{1 . 5}$ & 225 & $176-275$ \\
\hline $\mathbf{1 + 2}$ & 225 & $151-300$ \\
\hline $\mathbf{2}$ & 250 & $201-300$ \\
\hline $\mathbf{2 . 5}$ & 275 & $226-325$ \\
\hline $\mathbf{2 + 3}$ & 275 & $201-350$ \\
\hline $\mathbf{3}$ & 300 & $251-350$ \\
\hline $\mathbf{3 . 5}$ & 325 & $276-375$ \\
\hline $\mathbf{3 + 4}$ & 325 & $251-400$ \\
\hline $\mathbf{4}$ & 350 & $301-500$ \\
\hline $\mathbf{4 . 5}$ & 375 & $301-500$ \\
\hline $\mathbf{4 + 5}$ & 375 & $301-500$ \\
\hline $\mathbf{5}$ & 400 & $301-500$ \\
\hline
\end{tabular}

For some workers in the PIAAC sample, we do not have information at the 4-digit level available, but only at a more aggregate level (3-digit, 2-digit, or 1-digit). As indicated above, we dropped the respondents for which we had only 1-digit information available and for the remaining cases, we assigned the weighted average required level of the relevant underlying 4digit occupations and applied a range of 150 points ( 75 points above or below that weighted average) to define the well-matched for JAM (equivalent to the range for combined ratings). We followed the same procedure in the case of the 4-digit version of RMA (for the other versions of RMA and for PFM, this is not relevant as these are already defined at the 2-digit and 1-digit level respectively).

For the wage analysis we ran the following equation:

$$
\operatorname{LnW}_{\mathrm{ijc}}=\alpha_{\mathrm{c}}+\beta_{1} R S P_{\mathrm{j}}+\beta_{2} \mathrm{OS}_{\mathrm{ij}}+\beta_{3} \mathrm{US}_{\mathrm{ij}}+\beta_{4} \mathrm{C} 1_{\mathrm{ijc}}+\mathrm{U}_{\mathrm{ic}}+\omega_{\mathrm{c}}
$$

where $L_{n W} W_{i j c}$ is the natural log of the hourly wage of individual $i$ in unit group $j$ in country $c$; $\alpha_{c}$ is the country-specific constant; $R_{S P}$ the required skill level in unit group $\mathrm{j}, \mathrm{OS}_{\mathrm{ij}}$ and $\mathrm{US}_{\mathrm{ij}}$ are 
dummies for being overskilled and underskilled, $\mathrm{C}_{1 \mathrm{ijc}}$ is a vector of control variables ${ }^{4}$, including age, age squared, gender, working fulltime (i.e., working 32 hours or more per week), dummy for working in an occupation that has a combined rating and the share of self-employment in unit group $\mathrm{j}$ to account for the fact that the wage analyses excludes self-employed, while the ratings included them. The idiosyncratic error term at the individual level is represented by $U_{i c}$. We include country fixed effects. The standard errors are clustered by country.

For the job satisfaction analysis, we ran the following equation:

$J S_{i j c}=\alpha_{c}+\beta_{1} R S P_{j c}+\beta_{2} O S_{i j c}+\beta_{3} U S_{i j c}+\beta_{4} C 2_{i j c}+U_{i c}+\omega_{c}$

where $\mathrm{JS}_{\mathrm{ijc}}$ is the Job Satisfaction of the worker, and $\mathrm{C}_{\mathrm{ijc}}$ is a vector of control variables, including age, age squared, gender, working fulltime (i.e., working 32 hours or more per week), dummy for working in an occupation that has a combined rating and a dummy for being selfemployed. We look at the parameter estimates to evaluate the four measures.

\section{Results}

First, we look at the proportions of underskilled, well-matched, or overskilled workers according to the different methods. As indicated above, the RMA measure developed by Perry et al. (2014) differs in two aspects from the JAM measure we developed. First, it focuses on 2-digit instead of 4-digit occupations and second, the average realized match is calculated per country. To compare whether the difference between the two measures is related to any of these two differences, we also calculated the RMA using 2-digit occupations for all countries and using 4digit codes for all countries.

Table 3

Proportions underskilled, well-matched, and overskilled according to different methods

\begin{tabular}{|l|l|l|l|l|l|l|}
\hline Domain & Match & JAM & PFM & $\begin{array}{l}\text { RMA 2-digit } \\
\text { per country }\end{array}$ & $\begin{array}{l}\text { RMA 2-digit } \\
\text { all countries }\end{array}$ & $\begin{array}{l}\text { RMA 4-digit } \\
\text { all countries }\end{array}$ \\
\hline Numeracy & Underskilled & $22 \%$ & $6 \%$ & $12 \%$ & $14 \%$ & $14 \%$ \\
\hline & $\begin{array}{l}\text { Well- } \\
\text { matched }\end{array}$ & $61 \%$ & $84 \%$ & $76 \%$ & $72 \%$ & $73 \%$ \\
\hline & Overskilled & $17 \%$ & $10 \%$ & $12 \%$ & $14 \%$ & $13 \%$ \\
\hline & & & & & & \\
\hline Literacy & Underskilled & $19 \%$ & $6 \%$ & $11 \%$ & $12 \%$ & $12 \%$ \\
\hline & $\begin{array}{l}\text { Well- } \\
\text { matched }\end{array}$ & $58 \%$ & $85 \%$ & $80 \%$ & $76 \%$ & $77 \%$ \\
\hline & Overskilled & $23 \%$ & $9 \%$ & $10 \%$ & $11 \%$ & $11 \%$ \\
\hline
\end{tabular}

We can draw several conclusions from this comparison. First, we note that the proportion of well-matched workers differs considerably depending on the measure used. According to the JAM measure, some $60 \%$ of workers have the required literacy or numeracy skills for their job. But according to the different RMA-based measures, this is true for some $75 \%$ of the workers, while according to the PFM measure this holds for some $85 \%$ of the workers.

4. These control variables account for cross-occupational differences in the composition of the workforce. 
Second, we observe that for all three RMA-based measures the proportion of overskilled workers is roughly the same as the proportion of underskilled workers. However, in the case of JAM and PFM these proportions are different. This is directly related to how RMA-based measures are constructed. They define the average skilled worker in an occupation as being well-matched and define the overskilled or underskilled workers as those with a skill proficiency of one standard deviation above or below that average skill level. If the distribution of workers' skills proficiency levels within an occupation is symmetric (skewness is zero), we would expect the same proportions of overskilled and underskilled workers by definition. And this is what we observe. In the case of PFM, we observe a higher proportion of overskilled workers than underskilled workers for both numeracy and literacy, namely some $10 \%$ versus $6 \%$. In the case of JAM, we observe a clear difference. For numeracy the proportion of overskilled and underskilled workers are $17 \%$ and $22 \%$ respectively, while for literacy the order is reversed with $23 \%$ and $19 \%$ respectively.

Third, the difference between JAM and the RMA measure developed by Perry et al. (2014) is not caused by the fact that the latter is defined at the 2-digit level per country as all RMA-based measures provide roughly the same estimates.

How does this compare to what we know from estimates of incidence of educational mismatches in the literature? In a meta-analysis, Groot and Maassen van den Brink (2000) present an overall estimate of $23 \%$ overeducated workers and $14 \%$ undereducated workers. Quintini (2011) using an RMA-based measure on years of schooling and different data sources covering most OECD countries, estimates that one in four workers are overeducated and just over one in five are undereducated. Both estimates are closest to the estimate of JAM and very remote from the PFM measure.

In Table 4 we present the proportions of underskilled, well-matched, and overskilled workers per country. We restrict the overview for RMA-based measures to the 2-digit per country measure as developed by Perry et al. (2014). Countries are rank ordered by proportion of underskilled workers according to JAM. For each of the estimates we indicate the highest and the lowest percentage for the different measures across countries in bold and underlined italics respectively. 
Table 4a

Proportions underskilled (US), well-matched (WM), and overskilled (OS) workers per country: Numeracy

\begin{tabular}{|l|r|r|r|r|r|r|r|r|r|r|}
\hline & \multicolumn{3}{|c|}{ JAM } & \multicolumn{3}{|c|}{ PFM } & \multicolumn{3}{|r|}{ RMA 2-digit per country } \\
\hline & US & WM & OS & US & WM & OS & US & WM & OS \\
\hline Chile & $\mathbf{4 3}$ & $\mathbf{5 0}$ & $\mathbf{7}$ & $\mathbf{1 0}$ & $\mathbf{7 3}$ & $\mathbf{1 7}$ & $\mathbf{1 5}$ & $\mathbf{7 1}$ & $\mathbf{1 4}$ \\
\hline Mexico & 42 & $\underline{47}$ & 12 & 12 & $\underline{68}$ & $\mathbf{2 0}$ & 14 & 74 & 12 \\
\hline Israel & 34 & 55 & 11 & 5 & 85 & 10 & $\mathbf{1 7}$ & $\underline{66}$ & $\mathbf{1 7}$ \\
\hline Turkey & 34 & 52 & 14 & 3 & 89 & 8 & 14 & 72 & 14 \\
\hline Singapore & 32 & 59 & 9 & $\underline{2}$ & 88 & 10 & 16 & 68 & 16 \\
\hline Greece & 31 & 54 & 15 & $\mathbf{1 3}$ & 71 & 16 & 12 & 76 & 12 \\
\hline Slovenia & 28 & 60 & 12 & 4 & 86 & 10 & 13 & 76 & 11 \\
\hline United States & 28 & 60 & 13 & 3 & 89 & 8 & 14 & 72 & 14 \\
\hline Canada & 26 & 59 & 16 & 5 & 86 & 9 & 15 & 71 & 14 \\
\hline Ireland & 25 & 60 & 15 & 7 & 83 & 10 & 12 & 75 & 12 \\
\hline Italy & 25 & 60 & 15 & 5 & 83 & 12 & 13 & 76 & 12 \\
\hline New Zealand & 24 & 61 & 15 & 5 & 88 & 7 & 14 & 73 & 13 \\
\hline Spain & 24 & 59 & 17 & 6 & 79 & 15 & 12 & 77 & 11 \\
\hline France & 23 & 63 & 15 & 6 & 87 & 7 & 13 & 74 & 13 \\
\hline Poland & 22 & 61 & 18 & 7 & 79 & 14 & 13 & 75 & 12 \\
\hline Lithuania & 21 & 58 & 20 & 7 & 80 & 13 & 11 & 79 & 10 \\
\hline United Kingdom & 20 & 62 & 18 & 5 & 87 & 8 & 12 & 76 & 12 \\
\hline Denmark & 19 & 62 & 19 & 8 & 85 & 7 & 12 & 77 & 11 \\
\hline Estonia & 19 & 63 & 18 & 6 & 86 & 8 & 11 & 80 & 9 \\
\hline Korea & 17 & 59 & 24 & 6 & 86 & 9 & 10 & 80 & 10 \\
\hline Netherlands & 17 & 65 & 18 & 5 & $\mathbf{9 1}$ & $\underline{4}$ & 11 & 78 & 10 \\
\hline Norway & 16 & 65 & 19 & 7 & 87 & 6 & 11 & 77 & 12 \\
\hline Czech Republic & 16 & 64 & 20 & 4 & 88 & 8 & 9 & 82 & 9 \\
\hline Germany & 16 & 66 & 18 & 4 & 82 & 14 & 11 & 78 & 11 \\
\hline Austria & 16 & 66 & 18 & 5 & 76 & 19 & 11 & 79 & 10 \\
\hline Slovakia & 15 & 61 & 24 & 4 & 87 & 9 & $\underline{9}$ & $\mathbf{8 2}$ & 9 \\
\hline Sweden & 15 & $\mathbf{6 7}$ & 18 & 8 & 85 & 7 & 12 & 77 & 12 \\
\hline Hungary & 15 & 64 & 21 & 9 & 83 & 8 & 12 & 77 & 11 \\
\hline Belgium & 14 & 65 & 20 & 5 & 87 & 7 & 12 & 77 & 11 \\
\hline Finland & 13 & 7 & 87 & 7 & 11 & 78 & 10 \\
\hline Japan & 63 & 88 & 6 & 11 & 80 & 9,22 \\
\hline
\end{tabular}

Countries rank ordered by proportion underskilled workers according to JAM; percentages in bold denote the country with the highest proportion in that column, percentages in underlined italics denote the country with the lowest percentage. 
Table $4 b$

Proportions underskilled (US), well-matched (WM), and overskilled (OS) workers per country: Literacy

\begin{tabular}{|c|c|c|c|c|c|c|c|c|c|}
\hline & \multicolumn{3}{|c|}{ JAM } & \multicolumn{3}{|c|}{ PFM } & \multicolumn{3}{|c|}{ RMA 2-digit per country } \\
\hline & US & WM & OS & US & WM & OS & US & WM & OS \\
\hline Israel & 34 & 53 & 12 & 5 & 90 & $\underline{6}$ & 14 & $\underline{72}$ & 14 \\
\hline Singapore & 34 & 57 & $\underline{10}$ & $\underline{2}$ & 88 & 10 & 14 & 73 & 13 \\
\hline Chile & 32 & 56 & 12 & 13 & 76 & 11 & 12 & 76 & 12 \\
\hline Turkey & 32 & 52 & 16 & 4 & 86 & 11 & 11 & 81 & 9 \\
\hline Mexico & 31 & $\underline{51}$ & 18 & 12 & 77 & 11 & 13 & 76 & 11 \\
\hline Slovenia & 27 & 57 & 16 & 3 & 90 & 7 & 11 & 79 & 9 \\
\hline Greece & 27 & 53 & 21 & 15 & $\underline{70}$ & 15 & 12 & 77 & 11 \\
\hline Denmark & 24 & 58 & 18 & 7 & 85 & 8 & 11 & 80 & 9 \\
\hline Italy & 23 & 56 & 21 & 6 & 84 & 10 & 11 & 80 & 10 \\
\hline Lithuania & 23 & 51 & 26 & 7 & 79 & 14 & 9 & 83 & 8 \\
\hline Canada & 21 & 58 & 22 & 4 & 86 & 10 & 13 & 75 & 12 \\
\hline Spain & 20 & 56 & 24 & 6 & 81 & 13 & 12 & 78 & 10 \\
\hline France & 20 & 60 & 21 & 7 & 86 & 7 & 11 & 78 & 11 \\
\hline Estonia & 19 & 54 & 27 & 6 & 85 & 9 & 10 & 81 & 9 \\
\hline New Zealand & 18 & 59 & 23 & 6 & 88 & 7 & 11 & 79 & 10 \\
\hline Ireland & 18 & 60 & 22 & 9 & 83 & 8 & 11 & 80 & 10 \\
\hline United States & 18 & 61 & 21 & 5 & 87 & 8 & 12 & 78 & 10 \\
\hline Netherlands & 17 & 60 & 23 & 7 & 88 & 6 & 11 & 80 & 10 \\
\hline Sweden & 16 & 62 & 22 & 7 & 86 & 7 & 11 & 80 & 9 \\
\hline United Kingdom & 16 & 59 & 25 & 5 & 89 & 6 & 10 & 80 & 10 \\
\hline Slovakia & 16 & 55 & 30 & 4 & 86 & 10 & $\underline{8}$ & 86 & $\underline{6}$ \\
\hline Belgium & 15 & 60 & 24 & 5 & 89 & 6 & 10 & 80 & 10 \\
\hline Hungary & 15 & 61 & 24 & 8 & 85 & 7 & 9 & 84 & 7 \\
\hline Norway & 14 & 68 & 18 & 6 & 84 & 10 & 9 & 82 & 8 \\
\hline Austria & 14 & 66 & 20 & 6 & 83 & 10 & 9 & 83 & 7 \\
\hline Germany & 14 & 66 & 20 & 4 & 78 & 19 & 10 & 81 & 9 \\
\hline Czech Republic & 14 & 58 & 28 & 3 & 88 & 9 & 10 & 83 & 8 \\
\hline Poland & 13 & 56 & 31 & 8 & 84 & 7 & 12 & 78 & 10 \\
\hline Korea & 11 & 55 & 34 & 6 & 84 & 10 & 9 & 84 & 7 \\
\hline Finland & 11 & 58 & 32 & 7 & 86 & 7 & 11 & 79 & 10 \\
\hline Japan & $\underline{7}$ & 52 & 41 & 5 & 88 & 6 & 9 & 84 & 7 \\
\hline
\end{tabular}

Countries rank ordered by proportion underskilled workers according to JAM; percentages in bold denote the country with the highest proportion in that column, percentages in underlined italics denote the country with the lowest percentage.

We can observe several remarkable differences in the rank order of countries, depending on the skills mismatch measure. The proportion of underskilled workers for numeracy and literacy according to JAM ranges from a low $10 \%$ and $7 \%$ in Japan to a high $43 \%$ in Chile and $34 \%$ in Israel. In the case of PFM, the highest-ranking country is Greece with $13 \%$ and the lowestranking country is Singapore with $2 \%$. Note that these two countries both rank number 6 and 5 
in the rank order according to JAM. Similar discrepancies can be noted when comparing the RMA 2-digit per country measure with JAM or with PFM.

The above results indicate that the ranking of countries in terms of proportions underskilled, well-matched, or overskilled changes considerably if we use one or the other measure. This is best observed by looking at the correlations at the country level in Table 5.

Table 5

Correlation at the country level between different measures of mismatch

\begin{tabular}{|c|c|c|c|c|c|c|}
\hline & Numeracy & & & Literacy & & \\
\hline & JAM & PFM & $\begin{array}{l}\text { RMA 2-digit } \\
\text { per country }\end{array}$ & JAM & PFM & $\begin{array}{l}\text { RMA 2-digit } \\
\text { per country }\end{array}$ \\
\hline \multicolumn{7}{|l|}{$\begin{array}{l}\text { Proportion } \\
\text { underskilled }\end{array}$} \\
\hline JAM & 1 & & & 1 & & \\
\hline PFM & -0.04 & 1 & & 0.16 & 1 & \\
\hline $\begin{array}{l}\text { RMA 2-digit } \\
\text { per country }\end{array}$ & -0.81 & -0.01 & 1 & 0.67 & 0.11 & 1 \\
\hline \multicolumn{7}{|l|}{$\begin{array}{l}\text { Proportion } \\
\text { well-matched }\end{array}$} \\
\hline JAM & 1 & & & 1 & & \\
\hline PFM & 0.55 & 1 & & 0.16 & 1 & \\
\hline $\begin{array}{l}\text { RMA 2-digit } \\
\text { per country }\end{array}$ & 0.53 & 0.06 & 1 & 0.20 & 0.07 & 1 \\
\hline \multicolumn{7}{|l|}{$\begin{array}{l}\text { Proportion } \\
\text { overskilled }\end{array}$} \\
\hline JAM & 1 & & & 1 & & \\
\hline PFM & -0.37 & 1 & & -0.15 & 1 & \\
\hline $\begin{array}{l}\text { RMA 2-digit } \\
\text { per country }\end{array}$ & -0.80 & 0.07 & 1 & -0.60 & -0.04 & 1 \\
\hline & & & & & & \\
\hline
\end{tabular}

From Table 5 we can draw several conclusions. First, the correlations between the PFM measure and the RMA 2-digit per country are the lowest ranging from a low -0.04 (proportion overskilled workers in literacy) to 0.11 (proportion underskilled workers in literacy). This means that countries that rank high e.g., in the proportion well-matched according to PFM may rank low according to RMA and vice versa. Second, if we look at the proportion well-matched workers per country, we observe the highest correlations between JAM and the other two measures (both around 0.55), but this still means a correlation that is moderate at best, explaining only 25$30 \%$ of the between-country variation. Third, we observe strong negative correlations between the proportions of overskilled or underskilled workers in the domain of numeracy across countries when comparing JAM with both other measures. For literacy, we also observe negative correlations but only for the proportions of overskilled workers, while it is positive for the proportions of underskilled workers.

This means that for international comparisons, it really matters which measure is being used. Here it is good to consider that both PFM and the RMA 2-digit per country measures are calculated per country. Specifically, the RMA 2-digit per country measure assumes the average worker in a specific occupation and a specific country to be well-matched. But to able to 
compare the proportions underskilled or overskilled workers across countries, a common yardstick should be used. This could either be JAM or an RMA-based measure that is not calculated per country. Conceptually, the RMA 2-digit per country measure is therefore least likely to compare countries in a systematic way.

Which occupational unit groups have relative high levels of skill shortages or skill surpluses? Table 6 provides an overview of the top 3 occupational unit groups with the highest proportions of skill surpluses or skill shortages using the three different measures. 
Table 6

Top 3 of skill surpluses or skill shortages per occupational unit group using different skill mismatch measures

\begin{tabular}{|c|c|c|c|c|c|}
\hline Domain & Measure & Overskilled & $\%$ & Underskilled & $\%$ \\
\hline \multirow[t]{10}{*}{ Numeracy } & & Unit group & & Unit group & \\
\hline & JAM & 9622 Odd-job Persons & 84 & $\begin{array}{l}2230 \text { Traditional and } \\
\text { Complementary Medicine } \\
\text { Professionals }\end{array}$ & 80 \\
\hline & & 9334 Shelf Fillers & 83 & $\begin{array}{l}1343 \text { Aged Care Services } \\
\text { Managers }\end{array}$ & 76 \\
\hline & & $\begin{array}{l}9621 \text { Messengers, Package } \\
\text { Deliverers and Luggage } \\
\text { Porters }\end{array}$ & 82 & 3142 Agricultural Technicians & 75 \\
\hline & PFM & $\begin{array}{l}9623 \text { Meter Readers and } \\
\text { Vending-machine Collectors }\end{array}$ & 31 & 2355 Other Arts Teachers & 15 \\
\hline & & 5113 Travel Guides & 26 & $\begin{array}{l}2114 \text { Geologists and } \\
\text { Geophysicists }\end{array}$ & 15 \\
\hline & & $\begin{array}{l}4227 \text { Survey and Market } \\
\text { Research Interviewers }\end{array}$ & 25 & $\begin{array}{l}3255 \text { Physiotherapy } \\
\text { Technicians and Assistants }\end{array}$ & 14 \\
\hline & $\begin{array}{l}\text { RMA 2-digit } \\
\text { per country }\end{array}$ & $\begin{array}{l}5111 \text { Travel Attendants and } \\
\text { Travel Stewards }\end{array}$ & 30 & $\begin{array}{l}5212 \text { Street Food } \\
\text { Salespersons }\end{array}$ & 29 \\
\hline & & 5113 Travel Guides & 29 & $\begin{array}{l}9611 \text { Garbage and Recycling } \\
\text { Collectors }\end{array}$ & 28 \\
\hline & & $\begin{array}{l}3153 \text { Aircraft Pilots and } \\
\text { Related Associate } \\
\text { Professionals }\end{array}$ & 28 & $\begin{array}{l}3132 \text { Incinerator and Water } \\
\text { Treatment Plant Operators }\end{array}$ & 28 \\
\hline \multicolumn{6}{|l|}{ Literacy } \\
\hline & JAM & 9334 Shelf fillers & 89 & $\begin{array}{l}1343 \text { Aged Care Services } \\
\text { Managers }\end{array}$ & 76 \\
\hline & & 9622 Odd-job Persons & 87 & $\begin{array}{l}2114 \text { Geologists and } \\
\text { Geophysicists }\end{array}$ & 76 \\
\hline & & $\begin{array}{l}5111 \text { Travel Attendants and } \\
\text { Travel Stewards }\end{array}$ & 85 & 2352 Special Needs Teachers & 69 \\
\hline & PFM & $\begin{array}{l}5111 \text { Travel Attendants and } \\
\text { Travel Stewards }\end{array}$ & 25 & $\begin{array}{l}3132 \text { Incinerator and Water } \\
\text { Treatment Plant Operators }\end{array}$ & 17 \\
\hline & & $\begin{array}{l}4227 \text { Survey and Market } \\
\text { Research Interviewers }\end{array}$ & 25 & 3434 Chefs & 14 \\
\hline & & 5113 Travel Guides & 24 & $\begin{array}{l}2114 \text { Geologists and } \\
\text { Geophysicists }\end{array}$ & 12 \\
\hline & $\begin{array}{l}\text { RMA 2-digit } \\
\text { per country }\end{array}$ & $\begin{array}{l}5111 \text { Travel Attendants and } \\
\text { Travel Stewards }\end{array}$ & 37 & $\begin{array}{l}5212 \text { Street Food } \\
\text { Salespersons }\end{array}$ & 29 \\
\hline & & 6122 Poultry Producers & 34 & $\begin{array}{l}3132 \text { Incinerator and Water } \\
\text { Treatment Plant Operators }\end{array}$ & 28 \\
\hline & & 5113 Travel Guides & 32 & 9612 Refuse Sorters & 28 \\
\hline
\end{tabular}

A first thing to be noted is that the proportions overskilled and underskilled workers vary much more according to JAM than according to PFM and RMA 2-digit per country. This makes sense as the latter two are based on within-occupation variation, thus dampening extreme variation across occupations. Nevertheless, the JAM measure seems to produce very extreme results when we look at individual occupations. We will return to this issue later. 
According to JAM, we find the occupational unit groups with the highest proportions of overskilled workers in the Major Group 'Elementary Occupations': 'Odd-job Persons', 'Shelf Fillers', and 'Messengers, Package Deliverers and Luggage Porters'. This makes sense as the skill requirements in these jobs are very low, leading any worker with a literacy or numeracy level of 2 or above to be overskilled. But if we look at PFM or RMA 2-digit per country, we find most overskilled workers in the Major Group 'Services and Sales Workers'. The only occupational unit group where all three measures coincide, at least for literacy, is the unit group 'Travel Attendants and Travel Stewards'. Remarkably, we find unlikely high proportions of overskilled workers according to PFM in the occupational unit group 'Survey and Market Research Interviewers' (both numeracy and literacy) and according to RMA 2-digit per country in occupational unit group 'Aircraft Pilots and Related Associate Professionals' (only numeracy).

If we look at occupational unit groups with a high proportion of underskilled workers according to JAM, we find them in the Major Group 'Managers' ('Aged Care Services Managers'), Major Group 'Professionals' (e.g., 'Traditional and Complementary Medicine Professionals', 'Geologists and Geophysicists') and Major Group 'Technicians and Associate Professionals' ('Agricultural Technicians'). The only two occupational unit groups where we find some agreement between the different measures are 'Geologists and Geophysicists' (correspondence between JAM and PFM) and 'Incinerator and Water Treatment Plant Operators'

(correspondence between PFM and RMA 2-digit per country). Remarkably, we find unlikely high proportions of underskilled workers according to RMA 2-digit per country in the occupational unit groups 'Street Food Salespersons', 'Garbage and Recycling Collectors' and 'Refuse Sorters'.

Finally, Table 7 provides an overview of the 3 industrial sectors with the highest proportions of skill surpluses or skill shortages using JAM. 
Table 7

Top 3 of skill surpluses or skill shortages per sector using different skill mismatch measures

\begin{tabular}{|c|c|c|c|c|c|}
\hline Domain & Measure & Overskilled & $\%$ & Underskilled & $\%$ \\
\hline \multirow[t]{10}{*}{ Numeracy } & & Sector & & Sector & \\
\hline & JAM & $\begin{array}{l}\text { N Administrative and support } \\
\text { service activities }\end{array}$ & 35 & $\begin{array}{l}\text { A Agriculture; forestry and } \\
\text { fishing }\end{array}$ & 37 \\
\hline & & H Transportation and storage & 30 & $\begin{array}{l}\text { Q Human health and social } \\
\text { work activities }\end{array}$ & 30 \\
\hline & & $\begin{array}{l}\text { T Activities of households as } \\
\text { employers; undifferentiated } \\
\text { goods- and services-producing } \\
\text { activities of households for own } \\
\text { use }\end{array}$ & 29 & $\begin{array}{l}\text { M Professional, scientific and } \\
\text { technical activities }\end{array}$ & 29 \\
\hline & PFM & B Mining and quarrying & 16 & $\begin{array}{l}U \text { Activities of extraterritorial } \\
\text { organizations and bodies }\end{array}$ & 7 \\
\hline & & H Transportation and storage & 14 & $\begin{array}{l}\text { Q Human health and social } \\
\text { work activities }\end{array}$ & 6 \\
\hline & & $\begin{array}{l}\text { J Information and } \\
\text { communication }\end{array}$ & 14 & $\begin{array}{l}\text { A Agriculture; forestry and } \\
\text { fishing }\end{array}$ & 5 \\
\hline & $\begin{array}{l}\text { RMA 2- } \\
\text { digit per } \\
\text { country }\end{array}$ & B Mining and quarrying & 15 & $\begin{array}{l}\text { T Activities of households as } \\
\text { employers; undifferentiated } \\
\text { goods- and services-producing } \\
\text { activities of households for own } \\
\text { use }\end{array}$ & 20 \\
\hline & & $\begin{array}{l}\text { M Professional, scientific and } \\
\text { technical activities }\end{array}$ & 14 & $\begin{array}{l}\text { E Water supply; sewerage, } \\
\text { waste management and } \\
\text { remediation activities }\end{array}$ & 17 \\
\hline & & H Transportation and storage & 14 & $\begin{array}{l}\text { A Agriculture; forestry and } \\
\text { fishing }\end{array}$ & 16 \\
\hline \multicolumn{6}{|l|}{ Literacy } \\
\hline & JAM & $\begin{array}{l}\text { I Accommodation and food } \\
\text { service activities }\end{array}$ & 44 & P Education & 35 \\
\hline & & H Transportation and storage & 40 & $\begin{array}{l}\text { M Professional, scientific and } \\
\text { technical activities }\end{array}$ & 30 \\
\hline & & $\begin{array}{l}\text { N Administrative and support } \\
\text { service activities }\end{array}$ & 37 & $\begin{array}{l}\text { J Information and } \\
\text { communication }\end{array}$ & 26 \\
\hline & PFM & $\begin{array}{l}\text { U Activities of extraterritorial } \\
\text { organizations and bodies }\end{array}$ & 13 & $\begin{array}{l}\text { U Activities of extraterritorial } \\
\text { organizations and bodies }\end{array}$ & 7 \\
\hline & & $\begin{array}{l}\text { K Financial and insurance } \\
\text { activities }\end{array}$ & 12 & F Construction & 6 \\
\hline & & $\begin{array}{l}\mathrm{J} \text { Information and } \\
\text { communication }\end{array}$ & 12 & $\begin{array}{l}\text { A Agriculture; forestry and } \\
\text { fishing }\end{array}$ & 6 \\
\hline & $\begin{array}{l}\text { RMA 2- } \\
\text { digit per } \\
\text { country }\end{array}$ & B Mining and quarrying & 11 & $\begin{array}{l}\text { T Activities of households as } \\
\text { employers; undifferentiated } \\
\text { goods- and services-producing } \\
\text { activities of households for own } \\
\text { use }\end{array}$ & 18 \\
\hline & & $\begin{array}{l}\text { R Arts, entertainment and } \\
\text { recreation }\end{array}$ & 11 & $\begin{array}{l}\text { E Water supply; sewerage, } \\
\text { waste management and } \\
\text { remediation activities }\end{array}$ & 16 \\
\hline & & $\begin{array}{l}\text { I Accommodation and food } \\
\text { service activities }\end{array}$ & 11 & $\begin{array}{l}\text { A Agriculture; forestry and } \\
\text { fishing }\end{array}$ & 14 \\
\hline
\end{tabular}


When we look at the top 3 of sectors with overskilled workers, there is only one sector where all three measures overlap, namely 'Transportation and storage' (only for numeracy). The same holds for the proportion of underskilled workers, with 'Agriculture, forestry and fishing' being the only sector where all three measures overlap (again only for numeracy). In all other cases, the overlap is not systematic. This is not surprising as the differences by sector for a large extent capture aggregated differences by occupation and these rankings do not overlap either.

The next step in the analyses is to examine how the different skill measures predict relevant outcomes such as wages and job satisfaction. Table 8 provides the results for the wages.

Table 8

Wage effects of required skills, overskilling and underskilling using different skill mismatch measures

\begin{tabular}{|c|c|c|c|c|c|}
\hline \multicolumn{6}{|c|}{ Numeracy } \\
\hline VARIABLES & $\begin{array}{c}(1) \\
\text { JAM }\end{array}$ & $\begin{array}{c}\text { (2) } \\
\text { PFM }\end{array}$ & $\begin{array}{c}\text { (3) } \\
\text { RMA 2-digit } \\
\text { per country }\end{array}$ & $\begin{array}{c}\text { (4) } \\
\text { RMA 2-digit }\end{array}$ & $\begin{array}{c}\text { (5) } \\
\text { RMA 4-digit }\end{array}$ \\
\hline $\begin{array}{l}\text { Required skill } \\
\text { (std) }\end{array}$ & $\begin{array}{c}0.283^{* * *} \\
(0.015)\end{array}$ & $\begin{array}{l}0.314^{* * *} \\
(0.015)\end{array}$ & $\begin{array}{c}0.304^{* * *} \\
(0.013)\end{array}$ & $\begin{array}{c}0.242^{* * *} \\
(0.012)\end{array}$ & $\begin{array}{c}0.258^{* * *} \\
(0.012)\end{array}$ \\
\hline $\begin{array}{l}\text { Overskilled } \\
\text { dummy }\end{array}$ & $\begin{array}{c}0.162^{* * *} \\
(0.013)\end{array}$ & $\begin{array}{c}0.111^{* * *} \\
(0.008)\end{array}$ & $\begin{array}{l}0.107^{* * *} \\
(0.007)\end{array}$ & $\begin{array}{c}0.109^{* * *} \\
(0.008)\end{array}$ & $\begin{array}{c}0.098^{* * *} \\
(0.007)\end{array}$ \\
\hline $\begin{array}{l}\text { Underskilled } \\
\text { dummy }\end{array}$ & $\begin{array}{c}-0.148^{* * *} \\
(0.012)\end{array}$ & $\begin{array}{c}-0.159^{* * *} \\
(0.008)\end{array}$ & $\begin{array}{c}-0.124^{\star * *} \\
(0.008)\end{array}$ & $\begin{array}{c}-0.149^{* * *} \\
(0.016)\end{array}$ & $\begin{array}{c}-0.136^{\star * *} \\
(0.015)\end{array}$ \\
\hline Controls & Yes & Yes & Yes & Yes & Yes \\
\hline Country FE & Yes & Yes & Yes & Yes & Yes \\
\hline Observations & 84,078 & 83,208 & 84,078 & 84,078 & 84,078 \\
\hline R-squared & 0.627 & 0.631 & 0.636 & 0.636 & 0.641 \\
\hline \multicolumn{6}{|c|}{ Literacy } \\
\hline VARIABLES & $\begin{array}{l}(1) \\
\text { JAM }\end{array}$ & $\begin{array}{c}(2) \\
\text { PFM }\end{array}$ & $\begin{array}{c}\text { (3) } \\
\text { RMA 2-digit } \\
\text { per country }\end{array}$ & $\begin{array}{c}\text { (4) } \\
\text { RMA 2-digit }\end{array}$ & $\begin{array}{c}\text { (5) } \\
\text { RMA 4-digit }\end{array}$ \\
\hline $\begin{array}{l}\text { Required skill } \\
\text { (std) }\end{array}$ & $\begin{array}{c}0.291^{* * *} \\
(0.016)\end{array}$ & $\begin{array}{c}0.314^{* * *} \\
(0.014)\end{array}$ & $\begin{array}{c}0.302^{* * *} \\
(0.013)\end{array}$ & $\begin{array}{c}0.238^{* * *} \\
(0.012)\end{array}$ & $\begin{array}{c}0.253^{* * *} \\
(0.012)\end{array}$ \\
\hline $\begin{array}{l}\text { Overskilled } \\
\text { dummy }\end{array}$ & $\begin{array}{c}0.128^{* * *} \\
(0.013)\end{array}$ & $\begin{array}{c}0.106^{\star * *} \\
(0.006)\end{array}$ & $\begin{array}{c}0.098^{* * *} \\
(0.007)\end{array}$ & $\begin{array}{c}0.094^{* * *} \\
(0.009)\end{array}$ & $\begin{array}{l}0.084^{* * *} \\
(0.007)\end{array}$ \\
\hline $\begin{array}{l}\text { Underskilled } \\
\text { dummy }\end{array}$ & $\begin{array}{c}-0.104^{* * *} \\
(0.009)\end{array}$ & $\begin{array}{c}-0.143^{* * *} \\
(0.012)\end{array}$ & $\begin{array}{c}-0.119^{* * *} \\
(0.009)\end{array}$ & $\begin{array}{c}-0.140^{* * *} \\
(0.016)\end{array}$ & $\begin{array}{c}-0.129^{* * *} \\
(0.016)\end{array}$ \\
\hline Controls & Yes & Yes & Yes & Yes & Yes \\
\hline Country FE & Yes & Yes & Yes & Yes & Yes \\
\hline Observations & 84,078 & 83,208 & 84,078 & 84,078 & 84,078 \\
\hline R-squared & 0.637 & 0.626 & 0.629 & 0.629 & 0.634 \\
\hline
\end{tabular}

Robust standard errors in parentheses ${ }^{* * *} p<0.01,{ }^{* *} p<0.05,{ }^{*} p<0.1$

Controls include age, age squared, gender, fulltime worker, share of self-employment per occupation, and a dummy indicating whether the occupation was heterogeneous according to JAM (combined rating). 
In general, the explained variance is very high for all models with an R-square of around $64 \%$. If we first look at the estimates for required skill level, we note that the differences between the skill measures are small. Both JAM, PFM and the RMA 2-digit per country predict some $28 \%$ (range $25-31 \%$ ) increase in wages for every standard deviation increase in required skills. This holds for both numeracy and literacy. We also observe that the RMA-based measures that are not specified per country (columns 4 and 5) provide significantly lower estimates. This indicates that RMA-based measures that are not specified per country contain more noise. Note that the JAM measure does not suffer from the fact that it is based on across-country estimates of the required skill levels.

The main differences between the skills measures lie in the estimation of the effects for overskilling and underskilling. The PFM and RMA-based measures provide significantly lower estimates for the returns to being overskilled and - only for literacy - significantly higher penalties for being underskilled compared to the JAM measure. We also note that the penalties for being underskilled for these two measures are higher in absolute value than the returns to being overskilled. The JAM measure on the other hand provides results that are more in line with usual findings in the literature, namely that the returns to be being overskilled are larger in absolute value than the penalties of being underskilled (Hartog 2000; Groot and Maassen van den Brink 2000; Quintini 2011).

We conclude that the overall results do not differ that much between the different measures (looking at the proportion explained variance or the effect of required skills), but the wage effects of being overskilled or underskilled are probably more accurate for the JAM measure than for the alternative measures. This finding suggests that the wages are primarily based on inherent job requirements, instead of the average characteristics of their workers. If the latter would have been the case, the RMA-based measures would have been more likely to predict the wages correctly.

Table 9 provides the results for the analyses on job satisfaction. Job satisfaction is measured on a scale from 1 (Extremely dissatisfied) to 5 (Extremely satisfied). 
Table 9

Job satisfaction and effects of required skills, overskilling and underskilling using different skill mismatch measures

\begin{tabular}{|c|c|c|c|c|c|}
\hline \multicolumn{6}{|c|}{ Numeracy } \\
\hline & (1) & (2) & (3) & (4) & (5) \\
\hline VARIABLES & JAM & PFM & $\begin{array}{l}\text { RM 2-digit } \\
\text { per country }\end{array}$ & RM 2-digit & RMA 4-digit \\
\hline $\begin{array}{l}\text { Required skill } \\
\text { (std) }\end{array}$ & $\begin{array}{c}0.078^{* * *} \\
(0.008)\end{array}$ & $\begin{array}{l}0.105^{\star * *} \\
(0.018)\end{array}$ & $\begin{array}{l}0.095^{* * *} \\
(0.014)\end{array}$ & $\begin{array}{l}0.083^{* * *} \\
(0.007)\end{array}$ & $\begin{array}{l}0.088^{* * *} \\
(0.008)\end{array}$ \\
\hline $\begin{array}{l}\text { Overskilled } \\
\text { dummy }\end{array}$ & $\begin{array}{l}-0.014 \\
(0.013)\end{array}$ & $\begin{array}{c}-0.051^{* * *} \\
(0.011)\end{array}$ & $\begin{array}{l}-0.025^{*} \\
(0.009)\end{array}$ & $\begin{array}{c}-0.018^{* *} \\
(0.009)\end{array}$ & $\begin{array}{c}-0.033^{* * *} \\
(0.009)\end{array}$ \\
\hline $\begin{array}{l}\text { Underskilled } \\
\text { dummy }\end{array}$ & $\begin{array}{c}-0.018^{* *} \\
(0.009)\end{array}$ & $\begin{array}{l}-0.008 \\
(0.017)\end{array}$ & $\begin{array}{c}0.013 \\
(0.011)\end{array}$ & $\begin{array}{c}0.012 \\
(0.011)\end{array}$ & $\begin{array}{c}0.016 \\
(0.011)\end{array}$ \\
\hline Controls & Yes & Yes & Yes & Yes & Yes \\
\hline Country FE & Yes & Yes & Yes & Yes & Yes \\
\hline Observations & 103,113 & 100,387 & 103,114 & 103,114 & 103,113 \\
\hline R-squared & 0.074 & 0.075 & 0.074 & 0.076 & 0.076 \\
\hline
\end{tabular}

\begin{tabular}{|c|c|c|c|c|c|}
\hline \multicolumn{6}{|c|}{ Literacy } \\
\hline VARIABLES & $\begin{array}{l}(1) \\
\text { JAM }\end{array}$ & $\begin{array}{c}(2) \\
\text { PFM }\end{array}$ & $\begin{array}{c}(3) \\
\text { RM 2-digit per } \\
\text { country }\end{array}$ & $\begin{array}{c}\text { (4) } \\
\text { RMA 2-digit }\end{array}$ & $\begin{array}{c}\text { (5) } \\
\text { RMA 4-digit }\end{array}$ \\
\hline $\begin{array}{l}\text { Required skill } \\
\text { (std) }\end{array}$ & $\begin{array}{c}0.082^{* * *} \\
(0.009)\end{array}$ & $\begin{array}{c}0.108^{* * *} \\
(0.017)\end{array}$ & $\begin{array}{c}0.099^{* * *} \\
(0.014)\end{array}$ & $\begin{array}{l}0.085^{* * *} \\
(0.007)\end{array}$ & $\begin{array}{l}0.090^{* * *} \\
(0.008)\end{array}$ \\
\hline $\begin{array}{l}\text { Overskilled } \\
\text { dummy }\end{array}$ & $\begin{array}{c}-0.029^{* *} \\
(0.014)\end{array}$ & $\begin{array}{c}-0.047^{* * *} \\
(0.014)\end{array}$ & $\begin{array}{l}-0.021^{*} \\
(0.012)\end{array}$ & $\begin{array}{l}-0.018 \\
(0.011)\end{array}$ & $\begin{array}{c}-0.032^{* *} \\
(0.012)\end{array}$ \\
\hline $\begin{array}{l}\text { Underskilled } \\
\text { dummy }\end{array}$ & $\begin{array}{l}-0.001 \\
(0.008)\end{array}$ & $\begin{array}{l}-0.005 \\
(0.016)\end{array}$ & $\begin{array}{c}0.012 \\
(0.011)\end{array}$ & $\begin{array}{c}0.013 \\
(0.011)\end{array}$ & $\begin{array}{c}0.014 \\
(0.013)\end{array}$ \\
\hline Controls & Yes & Yes & Yes & Yes & Yes \\
\hline Country FE & Yes & Yes & Yes & Yes & Yes \\
\hline Observations & 103,113 & 100,387 & 103,114 & 103,114 & 103,113 \\
\hline R-squared & 0.077 & 0.075 & 0.075 & 0.076 & 0.077 \\
\hline
\end{tabular}

Robust standard errors in parentheses

${ }^{* * *} p<0.01,{ }^{* *} p<0.05,{ }^{*} p<0.1$

Controls include age, age squared, gender, fulltime worker, self-employed, and a dummy indicating whether the occupation was heterogeneous according to JAM (combined rating).

In general, the results are not very different if we compare the different measures. Overall, we observe that the explained variance is quite low (R-square is around $8 \%$ ) and the effects are quite small (and sometimes only significant at the 5 or $10 \%$ level). A one standard deviation increase in the required skill level is associated with less than one-tenth of a level increase on the scale for job satisfaction (with a range from 1-5). This implies that the level of required skills in an occupation only has a very small effect on the job satisfaction of workers. We also observe 
that the dummies for overskilling and underskilling are non-significant in 11 out of 20 cases and significant at the $1 \%$ level in only three cases. In two cases this relates to the PFM measure. Remember that this measure is partly based on the worker's self-assessment whether the skills possessed match with the skills required. This is in line with previous findings from Fregin (2019) that objective skill mismatches have no effect on job satisfaction, while subjective skill measures such as WSA are related to job satisfaction. In other words, whether a worker is satisfied with his or her job is related to whether he or she feels that the job does not match their own skill proficiency, and not whether there is 'real' mismatch in an objective sense. The PFM measure probably picks up this subjective element more than the JAM or RMA-based measures do.

\section{Conclusions, policy implications and limitations}

The PIAAC data are the leading source for information on skill proficiency levels for individuals in modern economies. The PIAAC data are unique in combining a validated assessment-based measurement of two key information-processing skills (i.e., literacy and numeracy) that are essential for developing a wide range of more specific skills with coverage of many OECD countries. However, to assess the degree of skill mismatch, one also needs to have information on the required skill level in the occupations in which these individuals work. That type of information is currently lacking in the PIAAC data. Although proxies of required skill levels have been used to estimate skill mismatch with the PIAAC data (e.g., Allen et al. 2013; Perry et al. 2014; Pellizzari and Fichen 2013, 2017), these proxies come with significant limitations (van der Velden and Bijlsma 2019).

In this paper, we applied the Job Analysis Method (JAM) to assess skill mismatches in the domains of literacy and numeracy. These key information-processing skills can be considered the most important skills that affect general functioning at work. In JAM, occupational experts identify the critical required skill level needed to execute the relevant tasks in the occupation. We compare JAM with two alternative measures: the Pellizari-Fichen (2013) model (PFM) and the Perry et al. (2014) model. Both alternative models use some form of Realised Matches Approach (RMA). In RMA, the average worker in an occupation is considered to be wellmatched and workers with a proficiency level of $1 \mathrm{sd}$ above or below that level as overskilled or underskilled. Perry et al. (2020) apply this on ISCO two-digit occupations per country (hence we refer to this as RMA 2-digit per country). The PFM model uses a restriction to this RMA by looking at workers who consider themselves well-matched and take their skill range to define the well-matched workers per one-digit occupation per country (regardless, whether these workers define themselves as well-matched or not).

The findings show that estimates of skill mismatch depend substantially on the method used. The proportion of well-matched workers is some $60 \%$ if we use JAM, some $75 \%$ if we use RMAbased measures and some $85 \%$ if we use PFM. At the same time, the JAM estimates of the proportions of overskilled workers and underskilled workers are higher than for the alternative measures. If we compare this to estimates of the prevalence of educational mismatches from the literature, with some $20-25 \%$ overeducated workers and $15-20 \%$ undereducated workers, we conclude that these are closest to the estimate of JAM and most remote from the PFM measure. 
Additionally, we find that the different methods lead to different conclusions when comparing countries. The correlations in the ranking of well-matched workers are only some .55, while the correlations in the ranking of overskilled (both literacy and numeracy) or underskilled (only numeracy) workers are negative when comparing JAM with the two other measures. Additionally, the correlation between PFM and RMA 2-digit is lower than 0.11 , indicating that ranking according to PFM is basically uncorrelated with a ranking according to RMA 2-digit.

This means that for international comparisons, it really matters which measure is being used. Given the fact that both PFM and the RMA 2-digit per country measures are calculated per country, there is good reason to believe that the JAM measure or RMA-based measures that are not calculated per country, provide more credible results as they use a common yardstick to compare countries.

Also, if we look at proportions overskilled or underskilled workers per occupation or per sector, we note that the JAM, PFM and RMA 2-digit per country come up with different sets of top 3s. Moreover, we note that in the overview of occupations with the highest percentages of overskilled or underskilled workers JAM shows occupations that appear to have more face validity than the two alternative measures. The main problem here is not so much the rank order of occupations that JAM provides, but rather the huge variation in these proportions leading to (unrealistic) high estimates for certain occupations. We will return to this later.

For the moment, we conclude that different methods yield quite different results if one is interested in the prevalence of skill mismatches and that there is good reason to believe that JAM provides the most accurate estimate of the absolute level of skill mismatches in the OECD as a whole, and also a better estimate in the relative ranking of countries or occupations when considering the proportion of workers that is seriously underskilled or overskilled.

This does not automatically imply that JAM is also better in predicting relevant outcomes related to skill mismatch. The relation with outcomes such as wages or job satisfaction is not only related to how well skill mismatch is measured, but also to how close the different measures capture the underlying mechanism driving these effects. If wages are solely driven by the inherent skill requirements of the job and the actual skills of the worker, we would expect JAM to be a superior predictor of wages. However, if wages are predominantly driven by the average characteristics of the workers, we would predict that RMA-based measures are a better predictor. In this paper we compared the different skill mismatch measures on their effect on wages and job satisfaction.

For wages, we find that the main differences between the mismatch measures are related to the effects of overskilling and underskilling on wages. We observe that the PFM- and RMA-based measures yield lower estimates for the wage returns to being overskilled, and (for literacy) higher wage penalties for being underskilled in comparison to the JAM-based measure. Additionally, whereas the PFM- and RMA-based measures suggest that the penalties for being underskilled are higher in absolute value than the returns to being overskilled, the JAM-based measure suggests the opposite, which is more in line with usual findings in the mismatch literature (Hartog 2000; Groot and Maassen van den Brink 2000; Quintini 2011). We therefore conclude that the JAM-based measure probably gives a more accurate estimation of the wage effects of skill mismatches than the alternative measures. Also, this implies that wages are mostly determined by inherent job requirements, rather than by the average characteristics of the workers in these jobs. 
For job satisfaction, our results do not suggest any major differences between the mismatch measures. The explained variance is generally quite low, which may partly be due to the limited variation in the job satisfaction measurement. All in all, we find that the level of required skills in an occupation is only modestly related to the job satisfaction of workers, and that there is generally no significant impact of overskilling and underskilling on job satisfaction. This suggests that workers' job satisfaction is not dependent on any measure of 'objectively' assessed skill mismatch (whether based on JAM, RMA or PFM). Instead, and in line with previous research, we argue that job satisfaction is related with subjective perceptions of the match between a worker's job and a worker's skills (see e.g., Fregin 2019). And in this association, reversed causality might very well drive the results in the sense that a low job satisfaction might make a worker feel mismatched.

\section{Policy implications}

The findings may have some important policy implications. Determining the objective requirements for occupations at an international level through this approach helps to paint a clearer picture of the actual prevalence of skill mismatch in Western economies. The results have pointed out that using different methods leads to widely varying estimates of the proportions of workers that are overskilled or underskilled. Moreover, using alternative methods such as PFM or RMA to determine skill mismatch may lead policy makers to underestimate the prevalence of underskilling and therefore inhibit policies to increase the skill levels of the working population. Moreover, JAM also seems to yield better estimates on the effects of skill mismatches on wages. As wages are regarded as a good proxy for productivity, this has also major implications for economic policy, for example in identifying which sectors and occupations suffer most from skill shortages or underskilling. Taken together, this implies that policy makers who aim to use the PIAAC data to examine skill mismatch should consider looking at the JAM method rather than any of the alternative methods.

However, this should also be done with caution. Overskilling or underskilling in the domain of literacy or numeracy skills, is different from identifying overall skill mismatches. Workers in an occupation who are uderskilled in numeracy might still be very productive in the job if they can compensate this with other skills, or when this is compensated in the team in which they are working. In that sense, all measures that were discussed here have a rather one-dimensional focus that does not do justice to the complexity of how workers with different skills can meet the different skill requirements at work. Looking at skill mismatch in just one domain, may therefore give a distorted view on the overall skill mismatch situation in a country, even if these domains are two of the critical key information-processing skills that are crucial for functioning well in the job. As said, this caution holds for JAM as well as for the other measures that identify skill mismatches in numeracy or literacy. For the future application of JAM, it is also good to consider its current limitations.

\section{Current limitations and directions for future research}

According to Hartog (2000), the purpose of JAM is objectivity, as trained occupational experts evaluate the job focusing on its technology and the type of activities to be done. Nonetheless, it can be questioned to what extent JAM is objective as it will always reflect the aggregated opinion of experts. Some of the results reflect that. We find much more variation across occupations using JAM than in using the other measures in terms of proportions overskilled or underskilled workers, with sometimes very extreme proportions ( $80 \%$ or above). Partly the stronger variation across occupations is realistic as the variation according to the alternative measures is downward-biased. Nevertheless, we feel that the variation is more extreme than 
would be expected on face validity and this is certainly true for the occupations at the upper end of the required skills levels. These are the occupations that were classified as requiring level 4 or 5 in numeracy or literacy proficiency. As indicated earlier, we already decided not to differentiate between levels 4 and 5 when determining the cut-off points for well-matched workers. This is also related to the extreme low percentages of PIAAC respondents reaching the highest level 5. As a follow-up, we suggest it would be good to crosscheck our estimates with the estimates of a broader panel of occupational experts and domain experts, specifically looking at the upper end of the job distribution.

Moreover, JAM as we applied it, assumes that occupations do not vary in required skill levels across countries. Notwithstanding the fact that ISCO is task-based, it is quite likely that the same coded occupation (e.g., carpenter) may still have different skill requirements in different countries. In the future it would be good to further develop our JAM estimates and check to what extent the different levels apply equally for the different countries. This would require the involvement of national occupational experts who could use the current estimates as a starting point and indicate to which extent these should be adjusted up or down.

Finally, the success of JAM critically relies on the existence of detailed and updated data, as highly aggregated classifications are prone to bias and can quickly become outdated (Dahlstedt 2011). This was the reason why during the project the occupational experts did not solely rely on the task descriptions in ISCO08. Some of these task descriptions were considered slightly out-of-date due to technological developments in the job, which may have affected working conditions and skill requirements in several jobs, and which will probably be updated in the upcoming revision of ISCO. The experts therefore also used their own insights and knowledge of occupations and national classifications. In this sense, it is fair to describe JAM as a normative approach, rather than an objective approach. However, it is this deep expert knowledge that is crucial for a successful application of JAM, and that contributes significantly to some of the strengths of this approach compared to other methods. 


\section{References}

Allen, Jim, and Rolf van der Velden. 2001. "Educational Mismatches versus Skill Mismatches: Effects on Wages, Job Satisfaction, and On-the-Job Search." Oxford Economic Papers 53 (3): 434-452.

---. 2005. The role of self-assessment in measuring skills. In REFLEX Working paper. Maastricht: Research Centre for Education and the Labour Market.

Cedefop. 2015. Skills, qualifications and jobs in the EU: the making of a perfect match? Evidence from Cedefop's European skills and jobs survey. Luxembourg: Publications Office.

Dahlstedt, Inge. 2011. "Occupational Match : Over- and Undereducation Among Immigrants in the Swedish Labor Market." Journal of International Migration and Integration 12 (3): 349367. https://doi.org/10.1007/s12134-010-0172-2.

Desjardins, Richard, and Kjell Rubenson. 2011. An Analysis of Skill Mismatch Using Direct Measures of Skills. Paris: OECD.

Dierdorff, E. C., and M. A. Wilson. 2003. "A meta-analysis of job analysis reliability." The Journal of applied psychology 88 (4): 635-46.

Duncan, Greg J., and Saul D. Hoffman. 1981. "The incidence and wage effects of overeducation." Economics of Education Review 1 (1): 75-86. https://doi.org/10.1016/02727757(81)90028-5.

Eurofound. 2012. Fifth European Working Conditions Survey - Overview report. Luxembourg: Publications Office of the European Union.

European Centre for the Development of Vocational Training. 2014. Terminology of European education and training policy: A selection of 130 key terms. Second edition. Luxembourg: Publications Office of the European Union.

Fregin, Marie-Christine M. 2019. Skill matching and outcomes: new cross-country evidence. Maastricht: Research Centre for Education and the Labour Market.

Global Agenda Council on Employment. 2014. Matching skills and labour market needs: Building social partnerships for better skills and better jobs. . Geneva: World Economic Forum.

Green, F., A. Felstead, and D. Gallie. 2013. "Skills and Work Organisation in Britain." In Job Tasks, Work Skills and the Labour Market, edited by F. Green and M. Keese. Paris: OECD Publishing.

Groot, W., and H. Maassen van den Brink. 2000. "Overeducation in the labor market: a metaanalysis." Economics of Education Review 19 (2): 149-158.

Hartog, J. 2000. "Over-education and earnings: Where are we, where should we go?" Economics of Education Review 19 (2): 131-147.

International Labour Organization. 2012. International Standard Classification of Occupations 2008 (ISCO-08): Structure, group definitions and correspondence tables. Geneva: International Labour Office.

Jenkins, Susan M., and Patrick Curtin. 2006. "Adapting Job Analysis Methodology to Improve Evaluation Practice." American Journal of Evaluation 27 (4): 485-494.

Levels, Mark, Rolf van der Velden, and Jim Allen. 2014. "Educational mismatches and skills: new empirical tests of old hypotheses." Oxford Economic Papers 66 (4): 959-982.

Lievens, F., and J. I. Sanchez. 2007. "Can training improve the quality of inferences made by raters in competency modeling? A quasi-experiment." The Journal of applied psychology 92 (3): 812-9.

McGowan, Muge Adalet, and Dan Andrews. 2017. Skills mismatch, productivity and policies: Evidence from the second wave of PIAAC. Paris: OECD.

McGuinness, Seamus. 2006. "Overeducation in the Labour Market." Journal of Economic Surveys 20 (3): 387-418. https://doi.org/10.1111/j.0950-0804.2006.00284.x. 
McGuinness, Seamus, Konstantinos Pouliakas, and Paul Redmond. 2018. "Skills Mismatch: Concepts, measurement and policy approaches." Journal of Economic Surveys 32 (4): 985-1015. https://doi.org/10.1111/joes.12254.

McGuinness, Seamus, and Mark Wooden. 2009. "Overskilling, Job Insecurity, and Career Mobility." Industrial Relations 48 (2): 265-286.

Mullins, Wayman C., and Wilson W. Kimbrough. 1988. "Group composition as a determinant of job analysis outcomes." Journal of Applied Psychology 73 (4): 657-664. https://doi.org/10.1037//0021-9010.73.4.657.

Muñoz de Bustillo Llorente, Rafael, Sudipa Sarkar, Raquel Sebastian, and Jose-Ignacio Antón. 2018. "Educational mismatch in Europe at the turn of the century." International Journal of Manpower 39 (8).

Nordin, Martin, Inga Persson, and Dan-Olof Rooth. 2010. "Education-occupation mismatch: Is there an income penalty?" Economics of Education Review 29 (6): 1047-1059. https://doi.org/10.1016/j.econedurev.2010.05.005.

O*NET. 2019. O*NET® 25.3 Database.

OECD. 2013a. OECD Skills Outlook 2013: First Results from the Survey of Adult Skills. Paris: OECD Publishing.

---. 2013b. The Survey of Adult Skills: Reader's Companion. Paris: OECD Publishing.

---. 2013c. Technical Report of the Survey of Adult Skills (PIAAC). Paris: OECD Publishing.

---. 2016. Getting skills right: Assessing and anticipating changing skill needs. Paris: OECD Publishing.

---. 2019. Skills Matter: Additional Results from the Survey of Adult Skills. OECD Publishing (Paris).

Pellizzari, Michele, and Anne Fichen. 2013. A new measure of skills mismatch: Theory and evidence from the survey of adult skills (PIAAC). edited by OECD Publishing. Paris.

---. 2017. A new measure of skill mismatch: theory and evidence from PIAAC. 6 (1): 1-30. https://doi.org/10.1186/s40172-016-0051-y.

Pérez Rodríguez, Sandra, Tim Huijts, Rolf van der Velden, and Babs Jacobs. 2020. Required literacy and numeracy skill levels for occupations in OECD countries: Application of the Job Analysis Method to PIAAC. Maastricht: Research Centre for Education and the Labour Market.

Perry, Anja, Simon Wiederhold, and Daniela Ackermann-Piek. 2014. How Can Skill Mismatch be Measured? New Approaches with PIAAC. Methoden, Daten, Analysen 8 (2): 137-174. https://doi.org/10.12758/mda.2014.006.

Quintini, Glenda. 2011. Right for the Job: Over-Qualified or Under-Skilled? Paris: OECD Publishing.

Sattinger, Michael. 1993. "Assignment Models of the Distribution of Earnings." Journal of Economic Literature 31 (2): 831-880.

---. 2012. Qualitative Mismatches. Foundations and Trends® in Microeconomics 8 (1-2): 1-168. https://doi.org/10.1561/0700000052.

Surrette, Michael A., Michael G. Aamodt, and Daniel L. Johnson. 1990. "Effects of Analyst Training and Amount of Available Job Related Information on Job Analysis Ratings." Journal of Business and Psychology 4 (4): 439-451.

van der Velden, Rolf, and Ineke Bijlsma. 2019. "Effective skill: a new theoretical perspective on the relation between skills, skill use, mismatches, and wages." Oxford Economic PapersNew Series 71 (1): 145-165.

van der Velden, Rolf, and M. S. M. van Smoorenburg. 1997. The measurement of overeducation and undereducation: self-report vs. job-analyst method.Research memorandum; ROARM-1997/2E. Maastricht: Research Centre for Education and the Labour Market.

van der Velden, Rolf, and Dieter Verhaest 2017. "Are skill deficits always bad? Towards a learning perspective on skill mismatches." Skill mismatch in labor markets, edited by S. W. 
Polachek, Konstantinos Pouliakas, Giovanni Russo and Konstantinos Tatamos, 305-343. United Kingdom: Emerald Publishing.

Verhaest, Dieter, and Eddy Omey. 2006. "Measuring the Incidence of Over- and Undereducation." Quality and Quantity 40 (5): 783-803.

Voskuijl, Olga F., and Tjarda van Sliedregt. 2002. "Determinants of Interrater Reliability of Job Analysis: A Meta-analysis." European Journal of Psychological Assessment 18 (1): 52-62. https://doi.org/10.1027//1015-5759.18.1.52.

Warr, P. 2007. Work, Happiness, and Unhappiness. New York: Routledge.

---. 2013. "Jobs and job-holders: Two sources of happiness and unhappiness." In The Oxford Handbook of Happiness, edited by S.A. David, I. Boniwell and A. C. Ayers. Oxford and New York: Oxford University Press.

Wolbers, Maarten, H. J. . 2003. "Job Mismatches and Their Labour-Market Effects among SchoolLeavers in Europe." European Sociological Review 19 (3): 249-266. 


\section{Supplementary materials}

\section{Appendix A: PIAAC Proficiency levels: literacy and numeracy}

The following table shows the different proficiency levels for literacy and numeracy from PIAAC (OECD 2013b). They range from 1 to 5 , including an extra category accounting for individuals whose proficiency level is below level 1. Participants are classified into each level based on their score on the tests, as shown in the table. An explanation of the tasks related to each level is also provided.

\begin{tabular}{|c|c|c|c|}
\hline Level & $\begin{array}{l}\text { Score } \\
\text { range }\end{array}$ & Literacy & Numeracy \\
\hline $\begin{array}{l}\text { Below } \\
1\end{array}$ & $\begin{array}{l}\text { Below } \\
176\end{array}$ & $\begin{array}{l}\text { The tasks at this level require the } \\
\text { respondent to read brief texts on } \\
\text { familiar topics to locate a single piece of } \\
\text { specific information. There is seldom } \\
\text { any competing information in the text } \\
\text { and the requested information is } \\
\text { identical in form to information in the } \\
\text { question or directive. The respondent } \\
\text { may be required to locate information in } \\
\text { short continuous texts. However, in this } \\
\text { case, the information can be located as } \\
\text { if the text was non-continuous in format. } \\
\text { Only basic vocabulary knowledge is } \\
\text { required, and the reader is not required } \\
\text { to understand the structure of } \\
\text { sentences or paragraphs or make use } \\
\text { of other text features. Tasks below } \\
\text { Level } 1 \text { do not make use of any features } \\
\text { specific to digital texts. }\end{array}$ & $\begin{array}{l}\text { Tasks at this level require the } \\
\text { respondents to carry out simple } \\
\text { processes such as counting, sorting, } \\
\text { performing basic arithmetic operations } \\
\text { with whole numbers or money, or } \\
\text { recognising common spatial } \\
\text { representations in concrete, familiar } \\
\text { contexts where the mathematical content } \\
\text { is explicit with little or no text or } \\
\text { distractors. }\end{array}$ \\
\hline 1 & $\begin{array}{l}176 \text { to } \\
\text { less } \\
\text { than } 226 \\
\text { points }\end{array}$ & $\begin{array}{l}\text { Most of the tasks at this level require the } \\
\text { respondent to read relatively short } \\
\text { digital or print continuous, non } \\
\text { continuous, or mixed texts to locate a } \\
\text { single piece of information that is } \\
\text { identical to or synonymous with the } \\
\text { information given in the question or } \\
\text { directive. Some tasks, such as those } \\
\text { involving non-continuous texts, may } \\
\text { require the respondent to enter } \\
\text { personal information onto a document. } \\
\text { Little, if any, competing information is } \\
\text { present. Some tasks may require }\end{array}$ & $\begin{array}{l}\text { Tasks at this level require the respondent } \\
\text { to carry out basic mathematical } \\
\text { processes in common, concrete contexts } \\
\text { where the mathematical content is } \\
\text { explicit with little text and minimal } \\
\text { distractors. Tasks usually require one- } \\
\text { step or simple processes involving } \\
\text { counting; sorting; performing basic } \\
\text { arithmetic operations; understanding } \\
\text { simple percentages such as } 50 \% \text {; and } \\
\text { locating and identifying elements of } \\
\text { simple or common graphical or spatial } \\
\text { representations. }\end{array}$ \\
\hline
\end{tabular}




\begin{tabular}{|c|c|c|c|}
\hline & & $\begin{array}{l}\text { simple cycling through more than one } \\
\text { piece of information. Knowledge and } \\
\text { skill in recognising basic vocabulary } \\
\text { determining the meaning of sentences, } \\
\text { and reading paragraphs of text is } \\
\text { expected. }\end{array}$ & \\
\hline 2 & $\begin{array}{l}226 \text { to } \\
\text { less } \\
\text { than } 276 \\
\text { points }\end{array}$ & $\begin{array}{l}\text { At this level, the medium of texts may } \\
\text { be digital or printed, and texts may } \\
\text { comprise continuous, non-continuous, } \\
\text { or mixed types. Tasks at this level } \\
\text { require respondents to make matches } \\
\text { between the text and information, and } \\
\text { may require paraphrasing or low-level } \\
\text { inferences. Some competing pieces of } \\
\text { information may be present. Some } \\
\text { tasks require the respondent to } \\
\text { - cycle through or integrate two or more } \\
\text { pieces of information based on criteria; } \\
\text { - compare and contrast or reason about } \\
\text { information requested in the question; } \\
\text { or } \\
\text { - navigate within digital texts to access- } \\
\text { and-identify information from various } \\
\text { parts of a document. }\end{array}$ & $\begin{array}{l}\text { Tasks at this level require the respondent } \\
\text { to identify and act on mathematical } \\
\text { information and ideas embedded in a } \\
\text { range of common contexts where the } \\
\text { mathematical content is fairly explicit or } \\
\text { visual with relatively few distractors. } \\
\text { Tasks tend to require the application of } \\
\text { two or more steps or processes involving } \\
\text { calculation with whole numbers and } \\
\text { common decimals, percentages and } \\
\text { fractions; simple measurement and } \\
\text { spatial representation; estimation; and } \\
\text { interpretation of relatively simple data } \\
\text { and statistics in texts, tables and graphs. }\end{array}$ \\
\hline 3 & $\begin{array}{l}276 \text { to } \\
\text { less } \\
\text { than } 326 \\
\text { points }\end{array}$ & $\begin{array}{l}\text { Texts at this level are often dense or } \\
\text { lengthy, and include continuous, non- } \\
\text { continuous, mixed, or multiple pages of } \\
\text { text. Understanding text and rhetorical } \\
\text { structures become more central to } \\
\text { successfully completing tasks, } \\
\text { especially navigating complex digital } \\
\text { texts. Tasks require the respondent to } \\
\text { identify, interpret, or evaluate one or } \\
\text { more pieces of information, and often } \\
\text { require varying levels of inference. } \\
\text { Many tasks require the respondent to } \\
\text { construct meaning across larger chunks } \\
\text { of text or perform multi-step operations } \\
\text { in order to identify and formulate } \\
\text { responses. Often tasks also demand } \\
\text { that the respondent disregard irrelevant } \\
\text { or inappropriate content to answer } \\
\text { accurately. Competing information is } \\
\text { often present, but it is not more } \\
\text { prominent than the correct information. }\end{array}$ & $\begin{array}{l}\text { Tasks at this level require the respondent } \\
\text { to understand mathematical information } \\
\text { that may be less explicit, embedded in } \\
\text { contexts that are not always familiar and } \\
\text { represented in more complex ways. } \\
\text { Tasks require several steps and may } \\
\text { involve the choice of problem-solving } \\
\text { strategies and relevant processes. Tasks } \\
\text { tend to require the application of number } \\
\text { sense and spatial sense; recognising and } \\
\text { working with mathematical relationships, } \\
\text { patterns, and proportions expressed in } \\
\text { verbal or numerical form; and } \\
\text { interpretation and basic analysis of data } \\
\text { and statistics in texts, tables and graphs. }\end{array}$ \\
\hline
\end{tabular}




\begin{tabular}{|c|c|c|c|}
\hline 4 & $\begin{array}{l}326 \text { to } \\
\text { less } \\
\text { than } 376 \\
\text { points }\end{array}$ & $\begin{array}{l}\text { Tasks at this level often require } \\
\text { respondents to perform multiple-step } \\
\text { operations to integrate, interpret, or } \\
\text { synthesise information from complex or } \\
\text { lengthy continuous, non-continuous, } \\
\text { mixed, or multiple type texts. Complex } \\
\text { inferences and application of } \\
\text { background knowledge may be needed } \\
\text { to perform the task successfully. Many } \\
\text { tasks require identifying and } \\
\text { understanding one or more specific, } \\
\text { non-central idea(s) in the text in order to } \\
\text { interpret or evaluate subtle } \\
\text { evidenceclaim or persuasive discourse } \\
\text { relationships. Conditional information is } \\
\text { frequently present in tasks at this level } \\
\text { and must be taken into consideration by } \\
\text { the respondent. Competing information } \\
\text { is present and sometimes seemingly as } \\
\text { prominent as correct information. }\end{array}$ & $\begin{array}{l}\text { Tasks at this level require the respondent } \\
\text { to understand a broad range of } \\
\text { mathematical information that may be } \\
\text { complex, abstract or embedded in } \\
\text { unfamiliar contexts. These tasks involve } \\
\text { undertaking multiple steps and choosing } \\
\text { relevant problem-solving strategies and } \\
\text { processes. Tasks tend to require } \\
\text { analysis and more complex reasoning } \\
\text { about quantities and data; statistics and } \\
\text { chance; spatial relationships; and } \\
\text { change, proportions and formulas. Tasks } \\
\text { at this level may also require } \\
\text { understanding arguments or } \\
\text { communicating well-reasoned } \\
\text { explanations for answers or choices. }\end{array}$ \\
\hline 5 & $\begin{array}{l}\text { Equal to } \\
\text { or } \\
\text { higher } \\
\text { than } 376 \\
\text { points }\end{array}$ & $\begin{array}{l}\text { At this level, tasks may require the } \\
\text { respondent to search for and integrate } \\
\text { information across multiple, dense } \\
\text { texts; construct syntheses of similar and } \\
\text { contrasting ideas or points of view; or } \\
\text { evaluate evidence based arguments. } \\
\text { Application and evaluation of logical } \\
\text { and conceptual models of ideas may be } \\
\text { required to accomplish tasks. } \\
\text { Evaluating reliability of evidentiary } \\
\text { sources and selecting key information is } \\
\text { frequently a requirement. Tasks often } \\
\text { require respondents to be aware of } \\
\text { subtle, rhetorical cues and to make } \\
\text { high-level inferences or use specialised } \\
\text { background knowledge. }\end{array}$ & $\begin{array}{l}\text { Tasks at this level require the respondent } \\
\text { to understand complex representations } \\
\text { and abstract and formal mathematical } \\
\text { and statistical ideas, possibly embedded } \\
\text { in complex texts. Respondents may have } \\
\text { to integrate multiple types of } \\
\text { mathematical information where } \\
\text { considerable translation or interpretation } \\
\text { is required; draw inferences; develop or } \\
\text { work with mathematical arguments or } \\
\text { models; and justify, evaluate and } \\
\text { critically reflect upon solutions or } \\
\text { choices. }\end{array}$ \\
\hline
\end{tabular}

Note. Adapted from OECD (2013b, 69-70) 


\section{Appendix B: Example of the information material provided to occupational experts}

\section{Physicists and Astronomers}

\section{Definition and Tasks:}

Physicists and astronomers conduct research and improve or develop concepts, theories and operational methods concerning matter, space, time, energy, forces and fields and the interrelationship between these physical phenomena. They apply scientific knowledge relating to physics and astronomy in industrial, medical, military or other fields.

Tasks include:

a) conducting research and improving or developing concepts, theories, instrumentation, software and operational methods related to physics and astronomy;

b) conducting experiments, tests and analyses on the structure and properties of matter in fields such as mechanics, thermodynamics, electronics, communications, power generation and distribution, aerodynamics, optics and lasers, remote sensing, medicine, sonics, magnetism and nuclear physics;

c) evaluating results of investigations and experiments and expressing conclusions, mainly using mathematical techniques and models;

d) applying principles, techniques and processes to develop or improve industrial, medical, military and other practical applications of the principles and techniques of physics or astronomy;

e) ensuring the safe and effective delivery of radiation (ionizing and non-ionizin) to patients to achieve a diagnostic or therapeutic result as prescribed by a medical practitioner;

f) ensuring the accurate measurement and characterization of physical quantities used in medical applications;

g) testing, commissioning and evaluating equipment used in applications such as imaging, medical treatment and dosimetry;

h) advising and consulting with medical practitioners and other health care professionals in optimizing the balance between the beneficial and deleterious effects of radiation;

i) observing, analysing and interpreting celestial phenomena and developing methods, numerical models and techniques to extend knowledge of fields such as navigation, satellite communication, space exploration, celestial bodies and cosmic radiation;

j) developing, implementing and maintaining standards and protocols for the measurement of physical phenomena and for the use of nuclear technology in industrial and medical applications;

k) preparing scientific papers and reports.

Examples of the occupations classified here: Astronomer, Medical physicist, Nuclear physicist, Physicist.

Some related occupations classified elsewhere: Radiation oncologist - 2212, Radiologist 2212, Specialist physician (nuclear medicine) - 2212, Radiographer -3211. 
It should be noted that, while they are appropriately classified in this unit group with other physicists, medical physicists are considered to be an integral part of the health workforce alongside those occupations classified in Sub-major Group 22: Health Professionals and others classified in a number of other unit groups in Major Group 2: Professionals

\section{Required Education and Experience:}

\begin{tabular}{|l|l|}
\hline Education: & $\begin{array}{l}\text { Most of these occupations require graduate school. For example, they may } \\
\text { require a master's degree, and some require a Ph.D. }\end{array}$ \\
\hline Experience: & $\begin{array}{l}\text { Extensive skill, knowledge, and experience are needed for these occupations. } \\
\text { Many require more than five years of experience. }\end{array}$ \\
\hline $\begin{array}{l}\text { Job } \\
\text { Training: }\end{array}$ & $\begin{array}{l}\text { Employees may need some on-the-job training, but most of these occupations } \\
\text { assume that the person will already have the required skills, knowledge, work- } \\
\text { related experience, and/or training. }\end{array}$ \\
\hline
\end{tabular}




\section{Appendix C: Required proficiency levels per 4-digit ISCO unit group}

The following table shows the required proficiency levels for literacy and numeracy according to JAM. The unit groups in bold represent the anchor occupations in each 2-digit Sub-Major Group.

\begin{tabular}{|c|c|c|c|}
\hline ISCO-08 & Occupation & Literacy & Numeracy \\
\hline 1111 & Legislators & Level 5 & Level 4 \\
\hline 1112 & Senior Government Officials & Level 5 & Level 4 \\
\hline 1113 & Traditional Chiefs and Heads of Villages & Level 3 & Level 3 \\
\hline 1114 & $\begin{array}{l}\text { Senior Officials of Special-interest } \\
\text { Organizations }\end{array}$ & Level 4.5 & Level 4 \\
\hline 1120 & Managing Directors and Chief Executives & Level 5 & Level 4 \\
\hline 1211 & Finance Managers & Level 5 & Level 4 \\
\hline 1212 & Human Resource Managers & Level 4.5 & Level 4 \\
\hline 1213 & Policy and Planning Managers & Level 5 & Level 4 \\
\hline 1219 & $\begin{array}{l}\text { Business Services and Administration } \\
\text { Managers Not Elsewhere Classified }\end{array}$ & Level 4 & Level 4 \\
\hline 1221 & Sales and Marketing Managers & Level 4.5 & Level 4 \\
\hline 1222 & $\begin{array}{l}\text { Advertising and Public Relations } \\
\text { Managers }\end{array}$ & Level 4.5 & Level 4 \\
\hline 1223 & Research and Development Managers & Level $4+5$ & Level $4+5$ \\
\hline 1311 & $\begin{array}{l}\text { Agricultural and Forestry Production } \\
\text { Managers }\end{array}$ & Level 4.5 & Level 4.5 \\
\hline 1312 & $\begin{array}{l}\text { Aquaculture and Fisheries Production } \\
\text { Managers }\end{array}$ & Level 4.5 & Level 4.5 \\
\hline 1321 & Manufacturing Managers & Level 4.5 & Level 4 \\
\hline 1322 & Mining Managers & Level 4.5 & Level 4 \\
\hline 1323 & Construction Managers & Level 4.5 & Level 4 \\
\hline 1324 & $\begin{array}{l}\text { Supply, Distribution and Related } \\
\text { Managers }\end{array}$ & Level 4.5 & Level 4 \\
\hline 1330 & $\begin{array}{l}\text { Information and Communications } \\
\text { Technology Services Managers }\end{array}$ & Level $4+5$ & Level $3+4$ \\
\hline 1341 & Child Care Services Managers & Level 4 & Level 4 \\
\hline
\end{tabular}




\begin{tabular}{|c|c|c|c|}
\hline 1342 & Health Services Managers & Level 5 & Level 4 \\
\hline 1343 & Aged Care Services Managers & Level 4 & Level 4 \\
\hline 1344 & Social Welfare Managers & Level 4 & Level 4 \\
\hline 1345 & Education Managers & Level $4+5$ & Level $3+4$ \\
\hline 1346 & $\begin{array}{l}\text { Financial and Insurance Services Branch } \\
\text { Managers }\end{array}$ & Level 4 & Level 4 \\
\hline 1349 & $\begin{array}{l}\text { Professional Services Managers Not } \\
\text { Elsewhere Classified }\end{array}$ & Level $4+5$ & Level 4 \\
\hline 1411 & Hotel Managers & Level $3+4$ & Level $3+4$ \\
\hline 1412 & Restaurant Managers & Level 3 & Level 3 \\
\hline 1420 & Retail and Wholesale Trade Managers & Level 3.5 & Level 4 \\
\hline 1431 & $\begin{array}{l}\text { Sports, Recreation and Cultural Centre } \\
\text { Managers }\end{array}$ & Level $3+4$ & Level $3+4$ \\
\hline 1439 & $\begin{array}{l}\text { Services Managers Not Elsewhere } \\
\text { Classified }\end{array}$ & Level $3+4$ & Level $3+4$ \\
\hline 2111 & Physicists and Astronomers & Level 4.5 & Level 5 \\
\hline 2112 & Meteorologists & Level 4.5 & Level 5 \\
\hline 2113 & Chemists & Level 4.5 & Level 5 \\
\hline 2114 & Geologists and Geophysicists & Level 4.5 & Level 5 \\
\hline 2120 & $\begin{array}{l}\text { Mathematicians, Actuaries and } \\
\text { Statisticians }\end{array}$ & Level 4.5 & Level 5 \\
\hline 2131 & $\begin{array}{l}\text { Biologists, Botanists, Zoologists and } \\
\text { Related Professionals }\end{array}$ & Level 4.5 & Level 4.5 \\
\hline 2132 & Farming, Forestry and Fisheries Advisers & Level 4.5 & Level 4 \\
\hline 2133 & $\begin{array}{l}\text { Environmental and Protection } \\
\text { Professionals }\end{array}$ & Level 4.5 & Level 4.5 \\
\hline 2141 & Industrial and Production Engineers & Level 4.5 & Level 4.5 \\
\hline 2142 & Civil Engineers & Level 4.5 & Level 5 \\
\hline 2143 & Environmental Engineers & Level 4.5 & Level 5 \\
\hline 2144 & Mechanical Engineers & Level 4.5 & Level 5 \\
\hline 2145 & Chemical Engineers & Level 4.5 & Level 5 \\
\hline
\end{tabular}




\begin{tabular}{|c|c|c|c|}
\hline 2146 & $\begin{array}{l}\text { Mining Engineers, Metallurgists and } \\
\text { Related Professionals }\end{array}$ & Level 4.5 & Level 5 \\
\hline 2149 & $\begin{array}{l}\text { Engineering Professionals Not Elsewhere } \\
\text { Classified }\end{array}$ & Level 4.5 & Level 5 \\
\hline 2151 & Electrical Engineers & Level 4.5 & Level 5 \\
\hline 2152 & Electronics Engineers & Level 4.5 & Level 5 \\
\hline 2153 & Telecommunications Engineers & Level 4.5 & Level 5 \\
\hline 2161 & Building Architects & Level 4.5 & Level 5 \\
\hline 2162 & Landscape Architects & Level 4.5 & Level 4 \\
\hline 2163 & Product and Garment Designers & Level 4 & Level $3+4$ \\
\hline 2164 & Town and Traffic Planners & Level 4.5 & Level 4.5 \\
\hline 2165 & Cartographers and Surveyors & Level 4.5 & Level 4.5 \\
\hline 2166 & Graphic and Multimedia Designers & Level 4 & Level 3.5 \\
\hline 2211 & Generalist Medical Practitioners & Level 5 & Level 4.5 \\
\hline 2212 & Specialist Medical Practitioners & Level 5 & Level 5 \\
\hline 2221 & Nursing Professionals & Level $3+4$ & Level 4 \\
\hline 2222 & Midwifery Professionals & Level 4 & Level 4 \\
\hline 2230 & $\begin{array}{l}\text { Traditional and Complementary Medicine } \\
\text { Professionals }\end{array}$ & Level 4 & Level 4 \\
\hline 2240 & Paramedical Practitioners & Level 4 & Level 4 \\
\hline 2250 & Veterinarians & Level 5 & Level 5 \\
\hline 2261 & Dentists & Level 5 & Level 4.5 \\
\hline 2262 & Pharmacists & Level 5 & Level 5 \\
\hline 2263 & $\begin{array}{l}\text { Environmental and Occupational Health } \\
\text { and Hygiene Professionals }\end{array}$ & Level 4 & Level 4.5 \\
\hline 2264 & Physiotherapists & Level 4 & Level 3.5 \\
\hline 2265 & Dieticians and Nutritionists & Level 4 & Level 4 \\
\hline 2266 & Audiologists and Speech Therapists & Level 4 & Level 4 \\
\hline 2267 & Optometrists and Ophthalmic Opticians & Level 4 & Level 4 \\
\hline 2269 & $\begin{array}{l}\text { Health Professionals Not Elsewhere } \\
\text { Classified }\end{array}$ & Level 4 & Level 4 \\
\hline 2310 & University and Higher Education Teachers & Level 5 & Level $4+5$ \\
\hline 2320 & Vocational Education Teachers & Level 4 & Level $3+4$ \\
\hline 2330 & Secondary Education Teachers & Level 4 & Level $3+4$ \\
\hline
\end{tabular}




\begin{tabular}{|c|c|c|c|}
\hline 2341 & Primary School Teachers & Level 3.5 & Level 3 \\
\hline 2342 & Early Childhood Educators & Level 3.5 & Level 2.5 \\
\hline 2351 & Education Methods Specialists & Level 5 & Level 4 \\
\hline 2352 & Special Needs Teachers & Level 4 & Level 3 \\
\hline 2353 & Other Language Teachers & Level 3.5 & Level 2.5 \\
\hline 2354 & Other Music Teachers & Level $3+4$ & Level 3 \\
\hline 2355 & Other Arts Teachers & Level $3+4$ & Level 2.5 \\
\hline 2356 & Information Technology Trainers & Level 4 & Level 4 \\
\hline 2359 & $\begin{array}{l}\text { Teaching Professionals Not Elsewhere } \\
\text { Classified }\end{array}$ & Level $3+4$ & Level $3+4$ \\
\hline 2411 & Accountants & Level $4+5$ & Level $4+5$ \\
\hline 2412 & Financial and Investment Advisers & Level $4+5$ & Level $4+5$ \\
\hline 2413 & Financial Analysts & Level 5 & Level 4.5 \\
\hline 2421 & Management and Organization Analysts & Level 5 & Level 4 \\
\hline 2422 & Policy Administration Professionals & Level 5 & Level 4 \\
\hline 2423 & Personnel and Careers Professionals & Level 4 & Level 3 \\
\hline 2424 & $\begin{array}{l}\text { Training and Staff Development } \\
\text { Professionals }\end{array}$ & Level 4 & Level 3 \\
\hline 2431 & Advertising and Marketing Professionals & Level 4 & Level 3.5 \\
\hline 2432 & Public Relations Professionals & Level 4 & Level 3.5 \\
\hline 2433 & $\begin{array}{l}\text { Technical and Medical Sales } \\
\text { Professionals (excluding ICT) }\end{array}$ & Level 4 & Level 4 \\
\hline 2434 & $\begin{array}{l}\text { Information and Communications } \\
\text { Technology Sales Professionals }\end{array}$ & Level 4 & Level 4 \\
\hline 2511 & Systems Analysts & Level 4.5 & Level 4.5 \\
\hline 2512 & Software Developers & Level 4.5 & Level 4 \\
\hline 2513 & Web and Multimedia Developers & Level 4.5 & Level 4 \\
\hline 2514 & Applications Programmers & Level 4.5 & Level 4 \\
\hline 2519 & $\begin{array}{l}\text { Software and Applications Developers and } \\
\text { Analysts Not Elsewhere Classified }\end{array}$ & Level 4.5 & Level 4 \\
\hline 2521 & Database Designers and Administrators & Level 4 & Level 4 \\
\hline
\end{tabular}




\begin{tabular}{|c|c|c|c|}
\hline 2522 & Systems Administrators & Level 3.5 & Level 3.5 \\
\hline 2523 & Computer Network Professionals & Level 4 & Level 4 \\
\hline 2529 & $\begin{array}{l}\text { Database and Network Professionals Not } \\
\text { Elsewhere Classified }\end{array}$ & Level 4 & Level 4 \\
\hline 2611 & Lawyers & Level 5 & Level 4 \\
\hline 2612 & Judges & Level 5 & Level 4 \\
\hline 2619 & $\begin{array}{l}\text { Legal Professionals Not Elsewhere } \\
\text { Classified }\end{array}$ & Level 5 & Level 4 \\
\hline 2621 & Archivists and Curators & Level 5 & Level 3.5 \\
\hline 2622 & $\begin{array}{l}\text { Librarians and Related Information } \\
\text { Professionals }\end{array}$ & Level 5 & Level 3.5 \\
\hline 2631 & Economists & Level 5 & Level 5 \\
\hline 2632 & $\begin{array}{l}\text { Sociologists, Anthropologists and Related } \\
\text { Professionals }\end{array}$ & Level 5 & Level 4 \\
\hline 2633 & $\begin{array}{l}\text { Philosophers, Historians and Political } \\
\text { Scientists }\end{array}$ & Level 5 & Level 4 \\
\hline 2634 & Psychologists & Level 5 & Level 4.5 \\
\hline 2635 & $\begin{array}{l}\text { Social Work and Counselling } \\
\text { Professionals }\end{array}$ & Level $4+5$ & Level $3+4$ \\
\hline 2636 & Religious Professionals & Level 5 & Level 3 \\
\hline 2641 & Authors and Related Writers & Level $4+5$ & Level 3 \\
\hline 2642 & Journalists & Level 5 & Level 3 \\
\hline 2643 & $\begin{array}{l}\text { Translators, Interpreters and Other } \\
\text { Linguists }\end{array}$ & Level 5 & Level 2.5 \\
\hline 2651 & Visual Artists & Level $3+4$ & Level 2 \\
\hline 2652 & Musicians, Singers and Composers & Level $3+4$ & Level $2+3$ \\
\hline 2653 & Dancers and Choreographers & Level $3+4$ & Level 2 \\
\hline 2654 & $\begin{array}{l}\text { Film, Stage and Related Directors and } \\
\text { Producers }\end{array}$ & Level 4.5 & Level $3+4$ \\
\hline 2655 & Actors & Level $3+4$ & Level 1 \\
\hline 2656 & $\begin{array}{l}\text { Announcers on Radio, Television and } \\
\text { Other Media }\end{array}$ & Level $3+4$ & Level $2+3$ \\
\hline
\end{tabular}




\begin{tabular}{|c|c|c|c|}
\hline 2659 & $\begin{array}{l}\text { Creative and Performing Artists Not } \\
\text { Elsewhere Classified }\end{array}$ & Level $2+3$ & Level $1+2$ \\
\hline 3111 & $\begin{array}{l}\text { Chemical and Physical Science } \\
\text { Technicians }\end{array}$ & Level 3 & Level 4 \\
\hline 3112 & Civil Engineering Technicians & Level 3 & Level 4 \\
\hline 3113 & Electrical Engineering Technicians & Level 3 & Level 4 \\
\hline 3114 & Electronics Engineering Technicians & Level 3 & Level 4 \\
\hline 3115 & Mechanical Engineering Technicians & Level 3 & Level 4 \\
\hline 3116 & Chemical Engineering Technicians & Level 3 & Level 4 \\
\hline 3117 & Mining and Metallurgical Technicians & Level 3 & Level 4 \\
\hline 3118 & Draughtspersons & Level 3 & Level 4 \\
\hline 3119 & $\begin{array}{l}\text { Physical and Engineering Science } \\
\text { Technicians Not Elsewhere Classified }\end{array}$ & Level 3 & Level 4 \\
\hline 3121 & Mining Supervisors & Level 3 & Level 3 \\
\hline 3122 & Manufacturing Supervisors & Level 3 & Level 3 \\
\hline 3123 & Construction Supervisors & Level 3 & Level 3 \\
\hline 3131 & Power Production Plant Operators & Level 3 & Level 3.5 \\
\hline 3132 & $\begin{array}{l}\text { Incinerator and Water Treatment Plant } \\
\text { Operators }\end{array}$ & Level 3 & Level 3.5 \\
\hline 3133 & Chemical Processing Plant Controllers & Level 3 & Level 3.5 \\
\hline 3134 & $\begin{array}{l}\text { Petroleum and Natural Gas Refining Plant } \\
\text { Operators }\end{array}$ & Level 3 & Level 3.5 \\
\hline 3135 & Metal Production Process Controllers & Level 2.5 & Level 3 \\
\hline 3139 & $\begin{array}{l}\text { Process Control Technicians Not } \\
\text { Elsewhere Classified }\end{array}$ & Level 3 & Level 3.5 \\
\hline 3141 & $\begin{array}{l}\text { Life Science Technicians (excluding } \\
\text { Medical) }\end{array}$ & Level 3 & Level 4 \\
\hline 3142 & Agricultural Technicians & Level 3 & Level 4 \\
\hline 3143 & Forestry Technicians & Level 3 & Level 4 \\
\hline 3151 & Ships' Engineers & Level 3 & Level 4 \\
\hline 3152 & Ships' Deck Officers and Pilots & Level 3 & Level 4 \\
\hline 3153 & $\begin{array}{l}\text { Aircraft Pilots and Related Associate } \\
\text { Professionals }\end{array}$ & Level 3 & Level 4 \\
\hline 3154 & Air Traffic Controllers & Level 3 & Level 4 \\
\hline
\end{tabular}




\begin{tabular}{|c|c|c|c|}
\hline 3155 & Air Traffic Safety Electronics Technicians & Level 3 & Level 4 \\
\hline 3211 & $\begin{array}{l}\text { Medical Imaging and Therapeutic } \\
\text { Equipment Technicians }\end{array}$ & Level 3 & Level $3+4$ \\
\hline 3212 & $\begin{array}{l}\text { Medical and Pathology Laboratory } \\
\text { Technicians }\end{array}$ & Level 3 & Level 4 \\
\hline 3213 & $\begin{array}{l}\text { Pharmaceutical Technicians and } \\
\text { Assistants }\end{array}$ & Level 3 & Level 3.5 \\
\hline 3214 & $\begin{array}{l}\text { Medical and Dental Prosthetic } \\
\text { Technicians }\end{array}$ & Level 2.5 & Level 3 \\
\hline 3221 & Nursing Associate professionals & Level 3 & Level 3 \\
\hline 3222 & Midwifery Associate professionals & Level 3 & Level 3 \\
\hline 3230 & $\begin{array}{l}\text { Traditional and Complementary Medicine } \\
\text { Associate Professionals }\end{array}$ & Level 3 & Level 2.5 \\
\hline 3240 & Veterinary Technicians and Assistants & Level 3 & Level 3 \\
\hline 3251 & Dental Assistants and Therapists & Level $2+3$ & Level 3 \\
\hline 3252 & $\begin{array}{l}\text { Medical Records and Health Information } \\
\text { Technicians }\end{array}$ & Level 3.5 & Level 3 \\
\hline 3253 & Community Health Workers & Level 3 & Level 3 \\
\hline 3254 & Dispensing Opticians & Level 2.5 & Level 3 \\
\hline 3255 & Physiotherapy Technicians and Assistants & Level 2.5 & Level 3 \\
\hline 3256 & Medical Assistants & Level 3 & Level 3 \\
\hline 3257 & $\begin{array}{l}\text { Environmental and Occupational Health } \\
\text { Inspectors and Associates }\end{array}$ & Level 3 & Level 3.5 \\
\hline 3258 & Ambulance Workers & Level $2+3$ & Level $2+3$ \\
\hline 3259 & $\begin{array}{l}\text { Health Associate Professionals Not } \\
\text { Elsewhere Classified }\end{array}$ & Level 3 & Level 3 \\
\hline 3311 & $\begin{array}{l}\text { Securities and Finance Dealers and } \\
\text { Brokers }\end{array}$ & Level 5 & Level 4 \\
\hline 3312 & Credit and Loans Officers & Level 3 & Level 3 \\
\hline 3313 & Accounting Associate Professionals & Level 3 & Level 3 \\
\hline 3314 & $\begin{array}{l}\text { Statistical, Mathematical and Related } \\
\text { Associate Professionals }\end{array}$ & Level 3 & Level 4 \\
\hline 3315 & Valuers and Loss Assessors & Level 3 & Level 3 \\
\hline 3321 & Insurance Representatives & Level 3 & Level 3 \\
\hline
\end{tabular}




\begin{tabular}{|c|c|c|c|}
\hline 3322 & Commercial Sales Representatives & Level 3 & Level 3 \\
\hline 3323 & Buyers & Level 4 & Level 4 \\
\hline 3324 & Trade Brokers & Level 3 & Level 3.5 \\
\hline 3331 & Clearing and Forwarding Agents & Level 2 & Level 2 \\
\hline 3332 & Conference and Event Planners & Level 2.5 & Level 2.5 \\
\hline 3333 & Employment Agents and Contractors & Level 2 & Level 1.5 \\
\hline 3334 & $\begin{array}{l}\text { Real Estate Agents and Property } \\
\text { Managers }\end{array}$ & Level 3 & Level 3 \\
\hline 3339 & $\begin{array}{l}\text { Business Services Agents Not Elsewhere } \\
\text { Classified }\end{array}$ & Level $2+3$ & Level $2+3$ \\
\hline 3341 & Office Supervisors & Level 2.5 & Level 2 \\
\hline 3342 & Legal Secretaries & Level 3 & Level 2.5 \\
\hline 3343 & Administrative and Executive Secretaries & Level 2.5 & Level 2 \\
\hline 3344 & Medical Secretaries & Level 3 & Level 2.5 \\
\hline 3351 & Customs and Border Inspectors & Level 3 & Level 3 \\
\hline 3352 & Government Tax and Excise Officials & Level 3 & Level 3 \\
\hline 3353 & Government Social Benefits Officials & Level 3 & Level 3 \\
\hline 3354 & Government Licensing Officials & Level 3 & Level 3 \\
\hline 3355 & Police Inspectors and Detectives & Level 4 & Level 3 \\
\hline 3359 & $\begin{array}{l}\text { Government Regulatory Associate } \\
\text { Professionals Not Elsewhere Classified }\end{array}$ & Level 3 & Level 3 \\
\hline 3411 & $\begin{array}{l}\text { Legal and Related Associate } \\
\text { Professionals }\end{array}$ & Level 3 & Level 3 \\
\hline 3412 & Social Work Associate Professionals & Level 3 & Level $2+3$ \\
\hline 3413 & Religious Associate Professionals & Level 2 & Level 1 \\
\hline 3421 & Athletes and Sports Players & Level $1+2$ & Level $1+2$ \\
\hline 3422 & Sports Coaches, Instructors and Officials & Level $2+3$ & Level $2+3$ \\
\hline 3423 & $\begin{array}{l}\text { Fitness and Recreation Instructors and } \\
\text { Programme Leaders }\end{array}$ & Level 2 & Level $2+3$ \\
\hline 3431 & Photographers & Level $2+3$ & Level 3 \\
\hline 3432 & Interior Designers and Decorators & Level $2+3$ & Level 3.5 \\
\hline
\end{tabular}




\begin{tabular}{|c|c|c|c|}
\hline 3433 & Gallery, Museum and Library Technicians & Level 2.5 & Level 2.5 \\
\hline 3434 & Chefs & Level 2.5 & Level 3 \\
\hline 3435 & $\begin{array}{l}\text { Other Artistic and Cultural Associate } \\
\text { Professionals }\end{array}$ & Level $2+3$ & Level $2+3$ \\
\hline 3511 & $\begin{array}{l}\text { Information and Communications } \\
\text { Technology Operations Technicians }\end{array}$ & Level 3 & Level 3 \\
\hline 3512 & $\begin{array}{l}\text { Information and Communications } \\
\text { Technology User Support Technicians }\end{array}$ & Level 3 & Level 3 \\
\hline 3513 & $\begin{array}{l}\text { Computer Network and Systems } \\
\text { Technicians }\end{array}$ & Level 3 & Level 3 \\
\hline 3514 & Web Technicians & Level 3 & Level 3 \\
\hline 3521 & Broadcasting and Audiovisual Technicians & Level 3 & Level 3 \\
\hline 3522 & $\begin{array}{l}\text { Telecommunications Engineering } \\
\text { Technicians }\end{array}$ & Level 3 & Level 4 \\
\hline 4110 & General Office Clerks & Level 2 & Level 2.5 \\
\hline 4120 & Secretaries (general) & Level 2 & Level 2 \\
\hline 4131 & Typists and Word Processing Operators & Level 2 & Level 1.5 \\
\hline 4132 & Data Entry Clerks & Level 1.5 & Level 2.5 \\
\hline 4211 & Bank Tellers and Related Clerks & Level 2 & Level 3 \\
\hline 4212 & $\begin{array}{l}\text { Bookmakers, Croupiers and Related } \\
\text { Gaming Workers }\end{array}$ & Level $1+2$ & Level $3+4$ \\
\hline 4213 & Pawnbrokers and Money-lenders & Level 1.5 & Level 3 \\
\hline 4214 & Debt Collectors and Related Workers & Level 2 & Level 2.5 \\
\hline 4221 & Travel Consultants and Clerks & Level 2.5 & Level 2 \\
\hline 4222 & Contact Centre Information Clerks & Level 2 & Level 2 \\
\hline 4223 & Telephone Switchboard Operators & Level 1 & Level 1 \\
\hline 4224 & Hotel Receptionists & Level 1.5 & Level 1 \\
\hline 4225 & Inquiry Clerks & Level 1 & Level 1 \\
\hline 4226 & Receptionists (general) & Level 1 & Level 1 \\
\hline 4227 & Survey and Market Research Interviewers & Level 2 & Level 1 \\
\hline 4229 & $\begin{array}{l}\text { Client Information Workers Not Elsewhere } \\
\text { Classified }\end{array}$ & Level $1+2$ & Level $1+2$ \\
\hline 4311 & Accounting and Bookkeeping Clerks & Level 2 & Level 2.5 \\
\hline
\end{tabular}




\begin{tabular}{|c|c|c|c|}
\hline 4312 & Statistical, Finance and Insurance Clerks & Level 2 & Level 2.5 \\
\hline 4313 & Payroll Clerks & Level 2 & Level 2.5 \\
\hline 4321 & Stock Clerks & Level 1 & Level 2 \\
\hline 4322 & Production Clerks & Level 2 & Level 2 \\
\hline 4323 & Transport Clerks & Level 2 & Level 2 \\
\hline 4411 & Library Clerks & Level 2 & Level 1.5 \\
\hline 4412 & Mail Carriers and Sorting Clerks & Level 2 & Level 1.5 \\
\hline 4413 & Coding, proofreading and related clerks & Level 2.5 & Level 1.5 \\
\hline 4414 & Scribes and Related Workers & Level 2 & Level 1 \\
\hline 4415 & Filing and Copying Clerks & Level 2 & Level 1.5 \\
\hline 4416 & Personnel Clerks & Level 2 & Level 1.5 \\
\hline 4419 & $\begin{array}{l}\text { Clerical Support Workers Not Elsewhere } \\
\text { Classified }\end{array}$ & Level 2 & Level 1.5 \\
\hline 5111 & Travel Attendants and Travel Stewards & Level 1 & Level 1.5 \\
\hline 5112 & Transport Conductors & Level 1 & Level 1 \\
\hline 5113 & Travel Guides & Level $2+3$ & Level 2 \\
\hline 5120 & Cooks & Level 1 & Level 2 \\
\hline 5131 & Waiters & Level 1 & Level 1.5 \\
\hline 5132 & Bartenders & Level 1 & Level 2 \\
\hline 5141 & Hairdressers & Level $0+1$ & Level $1+2$ \\
\hline 5142 & Beauticians and Related Workers & Level $0+1$ & Level $1+2$ \\
\hline 5151 & $\begin{array}{l}\text { Cleaning and Housekeeping Supervisors } \\
\text { in Offices, Hotels and Other } \\
\text { Establishments }\end{array}$ & Level 1 & Level 1 \\
\hline 5152 & Domestic Housekeepers & Level 0 & Level 0 \\
\hline 5153 & Building Caretakers & Level 0 & Level 0 \\
\hline 5161 & $\begin{array}{l}\text { Astrologers, Fortune-tellers and Related } \\
\text { Workers }\end{array}$ & Level 1.5 & Level 1 \\
\hline 5162 & Companions and Valets & Level 1.5 & Level 1 \\
\hline 5163 & Undertakers and Embalmers & Level $1+2$ & Level 2 \\
\hline 5164 & Pet Groomers and Animal Care Workers & Level 1.5 & Level 1 \\
\hline 5165 & Driving Instructors & Level 2 & Level 2 \\
\hline 5169 & $\begin{array}{l}\text { Personal Services Workers Not Elsewhere } \\
\text { Classified }\end{array}$ & Level $0+1$ & Level $0+1$ \\
\hline
\end{tabular}




\begin{tabular}{|c|c|c|c|}
\hline 5211 & Stall and Market salespersons & Level 1 & Level 1.5 \\
\hline 5212 & Street Food Salespersons & Level 0.5 & Level 1 \\
\hline 5221 & Shopkeepers & Level 2.5 & Level 3 \\
\hline 5222 & Shop Supervisors & Level 2 & Level 2 \\
\hline 5223 & Shop Sales Assistants & Level 1 & Level $1+2$ \\
\hline 5230 & Cashiers and Ticket Clerks & Level 1 & Level 2 \\
\hline 5241 & Fashion and Other Models & Level 0 & Level 0 \\
\hline 5242 & Sales Demonstrators & Level 1 & Level 0.5 \\
\hline 5243 & Door-to-door salespersons & Level 1 & Level 1 \\
\hline 5244 & Contact Centre Salespersons & Level 1.5 & Level 1 \\
\hline 5245 & Service Station Attendants & Level 1 & Level 1.5 \\
\hline 5246 & Food Service Counter Attendants & Level 1 & Level 1 \\
\hline 5249 & Sales Workers Not Elsewhere Classified & Level 1 & Level $1+2$ \\
\hline 5311 & Child Care Workers & Level 2.5 & Level 1.5 \\
\hline 5312 & Teachers' aides & Level 2.5 & Level 1.5 \\
\hline 5321 & Health Care Assistants & Level 2 & Level 1.5 \\
\hline 5322 & Home-based Personal Care Workers & Level 2.5 & Level 2 \\
\hline 5329 & $\begin{array}{l}\text { Personal Care Workers in Health Services } \\
\text { Not Elsewhere Classified }\end{array}$ & Level $1+2$ & Level $1+2$ \\
\hline 5411 & Firefighters & Level 2.5 & Level 2 \\
\hline 5412 & Police Officers & Level 3 & Level 2.5 \\
\hline 5413 & Prison Guards & Level 2 & Level 1 \\
\hline 5414 & Security Guards & Level 1.5 & Level 1 \\
\hline 5419 & $\begin{array}{l}\text { Protective Services Workers Not } \\
\text { Elsewhere Classified }\end{array}$ & Level 1 & Level 1 \\
\hline 6111 & Field Crop and Vegetable Growers & Level 2 & Level 3 \\
\hline 6112 & Tree and Shrub Crop Growers & Level 2 & Level 3 \\
\hline 6113 & $\begin{array}{l}\text { Gardeners; Horticultural and Nursery } \\
\text { Growers }\end{array}$ & Level 2 & Level 3 \\
\hline 6114 & Mixed Crop Growers & Level 2 & Level 3 \\
\hline 6121 & Livestock and Dairy Producers & Level 3 & Level 3 \\
\hline 6122 & Poultry Producers & Level 2.5 & Level 3 \\
\hline
\end{tabular}




\begin{tabular}{|c|c|c|c|}
\hline 6123 & Apiarists and Sericulturists & Level 2 & Level 2 \\
\hline 6129 & $\begin{array}{l}\text { Animal Producers Not Elsewhere } \\
\text { Classified }\end{array}$ & Level 2 & Level 2.5 \\
\hline 6130 & Mixed Crop and Animal Producers & Level $2+3$ & Level 3 \\
\hline 6210 & Forestry and Related Workers & Level 2 & Level 2 \\
\hline 6221 & Aquaculture Workers & Level 2 & Level 3 \\
\hline 6222 & $\begin{array}{l}\text { Inland and Coastal Waters Fishery } \\
\text { Workers }\end{array}$ & Level 2 & Level 2.5 \\
\hline 6223 & Deep-sea Fishery Workers & Level 2 & Level 2.5 \\
\hline 6224 & Hunters and Trappers & Level 1 & Level 2 \\
\hline 6310 & Subsistence Crop Farmers & Level 0 & Level 1 \\
\hline 6320 & Subsistence Livestock Farmers & Level 0 & Level 1 \\
\hline 6330 & $\begin{array}{l}\text { Subsistence Mixed Crop and Livestock } \\
\text { Farmers }\end{array}$ & Level 0 & Level 1 \\
\hline 6340 & $\begin{array}{l}\text { Subsistence Fishers, Hunters, Trappers } \\
\text { and Gatherers }\end{array}$ & Level 0 & Level 1 \\
\hline 7111 & House Builders & Level 1.5 & Level 2 \\
\hline 7112 & Bricklayers and Related Workers & Level 1.5 & Level 2 \\
\hline 7113 & $\begin{array}{l}\text { Stonemasons, Stone cutters, Splitters and } \\
\text { Carvers }\end{array}$ & Level 1.5 & Level 2 \\
\hline 7114 & $\begin{array}{l}\text { Concrete Placers, Concrete Finishers and } \\
\text { Related Workers }\end{array}$ & Level 1.5 & Level 2 \\
\hline 7115 & Carpenters and Joiners & Level 1.5 & Level 2 \\
\hline 7119 & $\begin{array}{l}\text { Building Frame and Related Trades } \\
\text { Workers Not Elsewhere Classified }\end{array}$ & Level 1.5 & Level 1.5 \\
\hline 7121 & Roofers & Level 1.5 & Level 2 \\
\hline 7122 & Floor Layers and Tile Setters & Level 1.5 & Level 2 \\
\hline 7123 & Plasterers & Level 1.5 & Level 2 \\
\hline 7124 & Insulation Workers & Level 1.5 & Level 2 \\
\hline 7125 & Glaziers & Level 1.5 & Level 2 \\
\hline 7126 & Plumbers and Pipe Fitters & Level 2 & Level 3 \\
\hline 7127 & $\begin{array}{l}\text { Air Conditioning and Refrigeration } \\
\text { Mechanics }\end{array}$ & Level 2 & Level 3 \\
\hline 7131 & Painters and Related Workers & Level 1.5 & Level 2 \\
\hline
\end{tabular}




\begin{tabular}{|c|c|c|c|}
\hline 7132 & Spray Painters and Varnishers & Level 1.5 & Level 2 \\
\hline 7133 & Building Structure Cleaners & Level 1 & Level 1 \\
\hline 7211 & Metal Moulders and Coremakers & Level 1.5 & Level 2.5 \\
\hline 7212 & Welders and Flame Cutters & Level 1.5 & Level 2 \\
\hline 7213 & Sheet Metal Workers & Level 1.5 & Level 2.5 \\
\hline 7214 & Structural Metal Preparers and Erectors & Level 1.5 & Level 2.5 \\
\hline 7215 & Riggers and Cable Splicers & Level 1.5 & Level 3 \\
\hline 7221 & $\begin{array}{l}\text { Blacksmiths, Hammersmiths and Forging } \\
\text { Press Workers }\end{array}$ & Level 1.5 & Level 2 \\
\hline 7222 & Toolmakers and Related Workers & Level 2 & Level 3 \\
\hline 7223 & $\begin{array}{l}\text { Metal Working Machine Tool Setters and } \\
\text { Operators }\end{array}$ & Level 2 & Level 3 \\
\hline 7224 & $\begin{array}{l}\text { Metal Polishers, Wheel Grinders and Tool } \\
\text { Sharpeners }\end{array}$ & Level 2 & Level 2 \\
\hline 7231 & Motor Vehicle Mechanics and Repairers & Level 2 & Level 3 \\
\hline 7232 & Aircraft Engine Mechanics and Repairers & Level 2.5 & Level 3 \\
\hline 7233 & $\begin{array}{l}\text { Agricultural and Industrial Machinery } \\
\text { Mechanics and Repairers }\end{array}$ & Level 2 & Level 3 \\
\hline 7234 & Bicycle and Related Repairers & Level 2 & Level 2 \\
\hline 7311 & $\begin{array}{l}\text { Precision-instrument Makers and } \\
\text { Repairers }\end{array}$ & Level 2 & Level 3 \\
\hline 7312 & Musical Instrument Makers and Tuners & Level 2 & Level 2.5 \\
\hline 7313 & Jewellery and Precious metal Workers & Level 2 & Level 2.5 \\
\hline 7314 & Potters and Related Workers & Level 2 & Level 2 \\
\hline 7315 & $\begin{array}{l}\text { Glass Makers, Cutters, Grinders and } \\
\text { Finishers }\end{array}$ & Level 2 & Level 2 \\
\hline 7316 & $\begin{array}{l}\text { Signwriters, Decorative Painters, } \\
\text { Engravers and Etchers }\end{array}$ & Level 2 & Level 2 \\
\hline 7317 & $\begin{array}{l}\text { Handicraft Workers in Wood, Basketry and } \\
\text { Related Materials }\end{array}$ & Level 1.5 & Level 2 \\
\hline 7318 & $\begin{array}{l}\text { Handicraft Workers in Textile, Leather and } \\
\text { Related Materials }\end{array}$ & Level 1.5 & Level 2 \\
\hline 7319 & $\begin{array}{l}\text { Handicraft Workers Not Elsewhere } \\
\text { Classified }\end{array}$ & Level 2 & Level 2.5 \\
\hline 7321 & Pre-press Technicians & Level 2 & Level 2.5 \\
\hline 7322 & Printers & Level 2 & Level 2.5 \\
\hline 7323 & Print Finishing and Binding Workers & Level 1.5 & Level 2 \\
\hline
\end{tabular}




\begin{tabular}{|c|c|c|c|}
\hline 7411 & Building and Related Electricians & Level 3 & Level 3.5 \\
\hline 7412 & Electrical Mechanics and Fitters & Level 2.5 & Level 3.5 \\
\hline 7413 & Electrical Line Installers and Repairers & Level 2 & Level 3.5 \\
\hline 7421 & Electronics Mechanics and Servicers & Level 2.5 & Level 3.5 \\
\hline 7422 & $\begin{array}{l}\text { Information and Communications } \\
\text { Technology Installers and Servicers }\end{array}$ & Level 3 & Level 3.5 \\
\hline 7511 & $\begin{array}{l}\text { Butchers, Fishmongers and Related Food } \\
\text { Preparers }\end{array}$ & Level 1 & Level 2 \\
\hline 7512 & $\begin{array}{l}\text { Bakers, Pastry-cooks and Confectionery } \\
\text { Makers }\end{array}$ & Level 1.5 & Level 2.5 \\
\hline 7513 & Dairy Products Makers & Level 1.5 & Level 2.5 \\
\hline 7514 & Fruit, Vegetable and Related Preservers & Level 1 & Level 2 \\
\hline 7515 & Food and Beverage Tasters and Graders & Level 2 & Level 2.5 \\
\hline 7516 & $\begin{array}{l}\text { Tobacco Preparers and Tobacco Products } \\
\text { Makers }\end{array}$ & Level 1 & Level 2 \\
\hline 7521 & Wood Treaters & Level 2 & Level 2 \\
\hline 7522 & Cabinet-makers and Related Workers & Level 2 & Level 3 \\
\hline 7523 & $\begin{array}{l}\text { Woodworking Machine Tool Setters and } \\
\text { Operators }\end{array}$ & Level 2 & Level 2 \\
\hline 7531 & Tailors, Dressmakers, Furriers and Hatters & Level 2 & Level 2.5 \\
\hline 7532 & $\begin{array}{l}\text { Garment and Related Patternmakers and } \\
\text { Cutters }\end{array}$ & Level 2 & Level 2.5 \\
\hline 7533 & Sewing, Embroidery and Related Workers & Level 1 & Level 1.5 \\
\hline 7534 & Upholsterers and Related Workers & Level 1.5 & Level 2 \\
\hline 7535 & Pelt Dressers, Tanners and Fellmongers & Level 1 & Level 2 \\
\hline 7536 & Shoemakers and Related Workers & Level 2 & Level 2.5 \\
\hline 7541 & Underwater Divers & Level $1+2$ & Level $2+3$ \\
\hline 7542 & Shotfirers and Blasters & Level 2.5 & Level 3 \\
\hline 7543 & $\begin{array}{l}\text { Product Graders and Testers } \\
\text { (excluding Foods and Beverages) }\end{array}$ & Level 2.5 & Level 3 \\
\hline 7544 & $\begin{array}{l}\text { Fumigators and Other Pest and Weed } \\
\text { Controllers }\end{array}$ & Level 1 & Level 2 \\
\hline 7549 & $\begin{array}{l}\text { Craft and Related Workers Not Elsewhere } \\
\text { Classified }\end{array}$ & Level 2 & Level 2 \\
\hline
\end{tabular}




\begin{tabular}{|c|c|c|c|}
\hline 8111 & Miners and Quarriers & Level 1.5 & Level 2 \\
\hline 8112 & $\begin{array}{l}\text { Mineral and Stone Processing Plant } \\
\text { Operators }\end{array}$ & Level 2 & Level 2 \\
\hline 8113 & $\begin{array}{l}\text { Well Drillers and Borers and Related } \\
\text { Workers }\end{array}$ & Level 2 & Level 2 \\
\hline 8114 & $\begin{array}{l}\text { Cement, Stone and Other Mineral } \\
\text { Products Machine Operators }\end{array}$ & Level 2 & Level 2 \\
\hline 8121 & Metal Processing Plant Operators & Level 2 & Level 2 \\
\hline 8122 & $\begin{array}{l}\text { Metal Finishing, Plating and Coating } \\
\text { Machine Operators }\end{array}$ & Level 2 & Level 2 \\
\hline 8131 & $\begin{array}{l}\text { Chemical Products Plant and Machine } \\
\text { Operators }\end{array}$ & Level 2 & Level 2 \\
\hline 8132 & Photographic Products Machine Operators & Level 2 & Level 2 \\
\hline 8141 & Rubber Products Machine Operators & Level 2 & Level 2 \\
\hline 8142 & Plastic Products Machine Operators & Level 2 & Level 2 \\
\hline 8143 & Paper Products Machine Operators & Level 2 & Level 2 \\
\hline 8151 & $\begin{array}{l}\text { Fibre Preparing, Spinning and Winding } \\
\text { Machine Operators }\end{array}$ & Level 2 & Level 2 \\
\hline 8152 & Weaving and Knitting Machine Operators & Level 2 & Level 2 \\
\hline 8153 & Sewing Machine Operators & Level 2 & Level 2 \\
\hline 8154 & $\begin{array}{l}\text { Bleaching, Dyeing and Fabric Cleaning } \\
\text { Machine Operators }\end{array}$ & Level 2 & Level 2 \\
\hline 8155 & $\begin{array}{l}\text { Fur and Leather Preparing Machine } \\
\text { Operators }\end{array}$ & Level 2 & Level 2 \\
\hline 8156 & $\begin{array}{l}\text { Shoemaking and Related Machine } \\
\text { Operators }\end{array}$ & Level 2 & Level 2 \\
\hline 8157 & Laundry Machine Operators & Level 1.5 & Level 2 \\
\hline 8159 & $\begin{array}{l}\text { Textile, Fur and Leather Products Machine } \\
\text { Operators Not Elsewhere Classified }\end{array}$ & Level 2 & Level 2 \\
\hline 8160 & $\begin{array}{l}\text { Food and Related Products Machine } \\
\text { Operators }\end{array}$ & Level 2 & Level 2 \\
\hline
\end{tabular}




\begin{tabular}{|c|c|c|c|}
\hline 8171 & Pulp and Papermaking Plant Operators & Level 2 & Level 2 \\
\hline 8172 & Wood Processing Plant Operators & Level 2 & Level 2 \\
\hline 8181 & Glass and Ceramics Plant Operators & Level 2 & Level 2 \\
\hline 8182 & Steam Engine and Boiler Operators & Level 2 & Level 2 \\
\hline 8183 & $\begin{array}{l}\text { Packing, Bottling and Labelling Machine } \\
\text { Operators }\end{array}$ & Level 1.5 & Level 2 \\
\hline 8189 & $\begin{array}{l}\text { Stationary Plant and Machine Operators } \\
\text { Not Elsewhere Classified }\end{array}$ & Level 2 & Level 2 \\
\hline 8211 & Mechanical Machinery Assemblers & Level 2 & Level 2 \\
\hline 8212 & $\begin{array}{l}\text { Electrical and Electronic Equipment } \\
\text { Assemblers }\end{array}$ & Level 2 & Level 2 \\
\hline 8219 & Assemblers Not Elsewhere Classified & Level 2 & Level 2 \\
\hline 8311 & Locomotive Engine Drivers & Level 1.5 & Level 2 \\
\hline 8312 & $\begin{array}{l}\text { Railway Brake, Signal and Switch } \\
\text { Operators }\end{array}$ & Level 2 & Level 2 \\
\hline 8321 & Motorcycle Drivers & Level 1 & Level 1 \\
\hline 8322 & Car, Taxi and Van Drivers & Level 1 & Level 1 \\
\hline 8331 & Bus and Tram Drivers & Level 1 & Level 1 \\
\hline 8332 & Heavy Truck and Lorry Drivers & Level 1 & Level 2 \\
\hline 8341 & Mobile Farm and Forestry Plant Operators & Level 1 & Level 1.5 \\
\hline 8342 & Earthmoving and Related Plant Operators & Level 1 & Level 1.5 \\
\hline 8343 & Crane, Hoist and Related Plant Operators & Level 1 & Level 2 \\
\hline 8344 & Lifting Truck Operators & Level 1 & Level 1.5 \\
\hline 8350 & Ships' Deck Crews and Related Workers & Level 1 & Level 1 \\
\hline 9111 & Domestic Cleaners and Helpers & Level 0 & Level 0 \\
\hline 9112 & $\begin{array}{l}\text { Cleaners and Helpers in Offices, Hotels } \\
\text { and other Establishments }\end{array}$ & Level 0 & Level 0 \\
\hline 9121 & Hand Launderers and Pressers & Level 0 & Level 0 \\
\hline 9122 & Vehicle Cleaners & Level 0 & Level 0 \\
\hline 9123 & Window Cleaners & Level 0 & Level 0 \\
\hline 9129 & Other Cleaning Workers & Level 0 & Level 0 \\
\hline
\end{tabular}




\begin{tabular}{|c|c|c|c|}
\hline 9211 & Crop Farm Labourers & Level 0 & Level 0 \\
\hline 9212 & Livestock Farm Labourers & Level 0 & Level 0 \\
\hline 9213 & Mixed Crop and Livestock Farm Labourers & Level 0 & Level 0 \\
\hline 9214 & Garden and Horticultural Labourers & Level 0 & Level 0 \\
\hline 9215 & Forestry Labourers & Level 0 & Level 0 \\
\hline 9216 & Fishery and Aquaculture Labourers & Level 0 & Level 0 \\
\hline 9311 & Mining and Quarrying Labourers & Level 0 & Level 0 \\
\hline 9312 & Civil Engineering Labourers & Level 0 & Level 0 \\
\hline 9313 & Building Construction Labourers & Level 0 & Level 0 \\
\hline 9321 & Hand Packers & Level 0 & Level 0 \\
\hline 9329 & $\begin{array}{l}\text { Manufacturing Labourers Not Elsewhere } \\
\text { Classified }\end{array}$ & Level 0 & Level 0 \\
\hline 9331 & Hand and Pedal Vehicle Drivers & Level 0 & Level 0 \\
\hline 9332 & $\begin{array}{l}\text { Drivers of Animal-drawn Vehicles and } \\
\text { Machinery }\end{array}$ & Level 0 & Level 0 \\
\hline 9333 & Freight Handlers & Level 0 & Level 0 \\
\hline 9334 & Shelf fillers & Level 0 & Level 0 \\
\hline 9411 & Fast Food Preparers & Level 0 & Level 0 \\
\hline 9412 & Kitchen Helpers & Level 0 & Level 0 \\
\hline 9510 & Street and Related Services Workers & Level 0 & Level 0 \\
\hline 9520 & Street Vendors (excluding Food) & Level 0 & Level 1 \\
\hline 9611 & Garbage and Recycling Collectors & Level 0 & Level 0 \\
\hline 9612 & Refuse Sorters & Level 0 & Level 0 \\
\hline 9613 & Sweepers and Related Labourers & Level 0 & Level 0 \\
\hline 9621 & $\begin{array}{l}\text { Messengers, Package Deliverers and } \\
\text { Luggage Porters }\end{array}$ & Level 0 & Level 0 \\
\hline 9622 & Odd-job Persons & Level 0 & Level 0 \\
\hline 9623 & $\begin{array}{l}\text { Meter Readers and Vending-machine } \\
\text { Collectors }\end{array}$ & Level 1 & Level 1 \\
\hline 9624 & Water and Firewood Collectors & Level 0 & Level 0 \\
\hline 9629 & $\begin{array}{l}\text { Elementary Workers Not Elsewhere } \\
\text { Classified }\end{array}$ & Level 0 & Level 0 \\
\hline
\end{tabular}


